\title{
第15回日本内分泌学会西部部会総会講演抄録（II )
}

昭和 42 年 9 月 28,29 日, 於京都会館, 会長 京大教授 深瀬政市

○印演者

80. Sephadex G $200 \mathrm{Gel}$ 濾過による血清分画中の Insulin に関する検討

京府医大吉田内科 吉田 秀雄, 奥村賢太郎, 進藤 岱三, 阿部 信行, 阿部 敦

○河野勝之祐, 油谷 桂朗, 飯田 優, 笹屋 昌文

第40回日本内分泌学会総会にて, 我々は血清を Sephadex G 75 にてゲル滤過を行ない, 蛋白分画 Fraction A, 非蛋白分画 Fraction B に分け，ILA，IRI を測定した結果，Fraction A に DILA に対する Inhibitor, FILA に対する Activator の存在するてとを報告した. 今回更に Fraction A を $\mathrm{pH}=7.4,0.15$ Mol 食塩水を展開液として Sephadex G 200 にてゲル濾過を行ない, Optical density により三つの分画 に分け, Tube Number の若いものより Fraction I, II, III とし, 各分画中の ILA, IRI を横隔膜法 (DILA), 副辠脂法 (FILA), Dextran coated charcoal immunoassay (IRI) にて測定した. 各分画中にいず れも DILA, FILA, IRI を認め，正常人血清と糖尿病患者血清による有意の差は認められなかつた。次に 各分画に結晶 Insulin $1000 \mu \mathrm{U} / \mathrm{ml}$ を添加したのち, その ILA を測定すると正常人血清では Fraction I に, 糖尿病患者血清では Fraction I, III に DILA に対する抑制効果を認めた. FILA では増強, 抑制の いずれも認められなかつた。

81. 簡易インスリン免疫学的測定, Radiosorb-I について

神戸大辻内科 辻 昇三, 馬場 茂明, 松岡 瑛, ○高石 務, 山口 吉彦 吉田 昌子, 伊集院幸一, 高橋 洋介, 甲賀 喻吉

1963年以来, 一抗体法, Resin 吸着法を検討し報告してきたが，今回測定操作上の問題点から, より一層 改良すべく, Immunoassay を臨床上 routin test として使用出来, 且手技的により簡易化した精度の高い 事を目的に清水製薬の協力を得て, 簡易測定キット, 仮称 Radiosorb-I を作成し，その有意性を検討し た. キットは次のものからなつている. 1) disporsable Test tube 2) G-G 400, OH 型 Resin 包入の disporsable F-B Separation Apparatus 3) Insulin Antiserum 4) Bovine Albumin Powder 5) Standard Insulin (Beef)

Standard curve, serum dilution test, recovery test, 正常人 GTT に於ける IRI 反応等によつて一応 immuno reactive insulin を測定し得ることが確かめられ, 臨床検査として簡易で且, 精度の高いてとによ り利用価值があるものと考える。

質問：京府医大吉田内科 阿部 信行 1) Resin は分子量についてどれ位のあのまで吸着されるか.

2)との方法は Insulin 以外の Peptide Hormone の測定に利用され得るか.

質 問：京大深瀬内科 桜井 英雄 Kit についている Standard は何の Insulin か.

質 問：岐阜大早瀬内科 竹内 三郎 Radiosorb 法と二抗体法の間に何か測定結果に差はないか.

応答：神大辻内科高石務 (1) Resin に吸着する分子量は不明であるが, 他のホルモンの免疫学 的測定に利用しうる希望をもつている. (2)キット内の Standard insulin にはブタを使用している. (2)二抗 体法との比較は検討中であるがほほ平行する.

応答：神大辻内科馬場 茂明 1) Standard curve 作成上では二抗体法 (Morgan Lazarow 法) と 差がない，2）実地応用上に未だ二，三の検討を加えてみたいと考えている．しかし手技等従来の方法より 簡便化し，且再現性もあるので応用性が十分あると考えている.

82. 門脈血中インスリン值測定の試み(子報)

岐阜大早瀬内科＼cjkstart阿知波秀夫, 橋本 明憲, 森 矩尉, 竹内 三郎 岐阜大中央手術室 早野董

〔目的，方法〕近年血中インスリンの測定が広く行なわれる様になつてきたが，膵静脈は門脈にそそいで 
いるので門脈血についてインスリン量の測定を行なうならば，その分泌動態をより鋭敏に反映するであろう と思われる．私達は開腹術を受けた患者について手術中に臍静脈疏通法によりカテーテルを門脈内に插入し， 糖負荷による血中インスリン值及び血糖值を末梢血，門脈血の両者について同時に測定した．糖負荷は経口 法, 静注法の両者を併用した。〔成績〕血糖曲線は門脈血，末梢血共ほぼ同様の值を示し，いずれも軽度糖 尿病型を呈した．インスリン值は門脈血においては末梢血にくらべて全ての例で数倍の感度で反応した. 未 梢血で糖負荷によるインスリン反応のみられない場合でも, 門脈血ではあきらかな反応を示した. 又経口法, 静注法の比較においては血糖值がほぼ同程度であるのにインスリン值が大きな差を示した. 経口負荷の場合 は腸管粘膜よりインスリン分泌促進に働く因子が推定されているが，同様の結果を門脈血インスリン值が明 らかに示した例と思われる。〔結論〕門脈血インスリン值は未梢血インスリン值に比べて数倍の感度で反応 するものと考えられ, 膵ラ氏島のインスリン分泌動態, とくに微細な分泌動態を同うに本法は強力な武器と なるものと思われる.

質問：京府医大吉田内科 阿部 信行 1) 静脈血の Insulin 反応が著明でないのは処置を施している 為か. 処置していない時あ反応しないのか. 2) 空腹時は静脈血と門脈血の IRI は大体同程度であるが糖負 荷後門脈血中の IRI が非常に高い. これは糖負荷後の Insulin の方が末梢に出るまで inactivateされや すいと考えて良いか.

応 答：岐阜大早瀬内科 竹内 三郎 門脈血インスリン值は分泌相において高値を占めるのであつて静 止相では末梢血と差が少ないものと考えている.

質問：徳島大油谷内科 尾上 久吾 経口的 GTT 及び glucose に対する insulin response curve で Insulin mangel diabetes と考えられる症例であ尚門脈中の Insulin では Insulin の分泌が充分であると か或はそうでないとかという所見がみられているか.

追加：阪大西川内科島健二 静脈内糖負荷に於ける IRI 反応が低いのは採血時間に問題がある と思う。我々の経験では負荷約 4 分で最高值に達し20分では殆んど前值に復帰している。経口負荷時に静脈 内負荷時に比し IRI の反応が大と云われる前に採血時間を検討される事が必要と思う.

質問：神大辻内科 馬場 茂明 1) 胃切除術を行なつた患者で，同時にVagotomyを施行した場合と 非施行時に IRI 反応飞差がみられたかどうか. 2) 糖の腸管注入を小腸下部で行なつたときと経口投与で門 脈 IRI 反応に差があるかどうか.

83. Insulin 分泌におよぼす自律神経薬物の影暗

九大勝木内科 伊東 三夫, 山本 登士, 田中 正人, 中島 敏郎

丸山 俊之, 平田 幸正, 勝木司馬之助

$10 \mathrm{~kg}$ 内外の成犬を用い股静脈より採血し，各種の自律神経薬物投与時の Insulin 分泌反応を検討した.

1) Adrenaline $0.1 \mathrm{mg} / \mathrm{kg}$ を 1 時間で点滴投与した際は血糖および FFA は著名に上昇したが，末梢血中 Insulin (IRI) は前值と変らず，中止直後に軽度の一過性増量が認められた. Adrenaline $0.2 \mathrm{mg} / \mathrm{kg}$ を 1 時 間で点滴投与した際には，血糖，FFA ともに著明に増加したが，血中 IRI は前值にとどまり，点滴中止 後漸次増加する傾向がみられた。 ブドー糖 1.3-1.9g/kg/hour を 3 時間にわたつて点滴投与中，中央の 1 時 間で Adrenaline $0.2 \mathrm{mg} / \mathrm{kg}$ を追加点滴投与した. 初めの 1 時間では血糖 IRI ともに平行して増加した。 Adrenaline 投与と共に血糖は著明に増加したが IRI は直ちに抑制され前值近くに下降した. Adrenaline 中止後は IRI の著明な増加がみられた。 2) Isoproterenol $0.03 \mathrm{mg} / \mathrm{kg}$ を 1 時間で点滴した際は血糖の上昇 は軽度であつたが IRI は著明に増加し投与中止と共に急速に下降した． Isoproterenol $0.02 \mathrm{mg} / \mathrm{kg}$ を 1 時 間で点滴投与中，30分目に Propranolol 2.5mg を静注すると前述の IRI の著増は直ちに抑制された. 3) Vagostigmine $0.05 \mathrm{mg} / \mathrm{kg}$ を 1 時間で点滴投与した際には血糖，IRI とも著変は認めなかつた，以上の成績 より，交感神経 $\alpha$ receptor の刺激は Insulin の抑制を， $\beta$ receptor の刺激は Insulin の増加をもたらす. すなわち交感神経系は Insulin 分泌調節に重要な影響があるものと考えられる.

質問：岐阜大早瀬内科 竹内 三郎 (1)ンスリン分泌に対するアドレナリンの作用として脺動脈への 
作用を介してと直接の作用とが考えられるが，どのような考えか. (2)直接作用とすればラ氏島 $\beta$ 細胞に Adrenergic $\beta$ receptor の存在を考えておられるか.

追加：京大深瀬内科 池田 正毅 我々も自律神経系薬剂のインスリン分泌住する対す影響に興味を持ち， 特異な例ではあるが, エピネフリン過剩症である褐色細胞腫につき検討した。褐色細胞腄術前, 術後に50G GTT を行なうと術前では殆んど diabetic curve を示し, インスリンの反応は低下逮延しているが, 術後

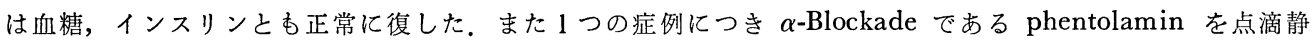
注しブドウ糖を負荷すると著明なインスリン反応を見るのでなく $\beta$-Blockade である propranolol を同様 に点滴静注したが，インスリンの反応は見られなかつたエピネフリン過剩時のインスリン抑制作用は $\alpha$ 一作 用を介するものと思われる。

応 答 : 九大勝木内科 伊東 三夫 質問飞対する応答 : 血管を介するすのとは考えにくく, $\beta$ 細胞に直 接作用するあのと考元ている。併し作用の機序については今後の検討が必要である。追加に対する応答： Pheochromocytoma の際の Insulin 分泌抑制の様相は私共が動物に stressを附与した際のInsulin の消 長と極めて類似しており， stress 時に分泌される Adrenaline が主要な役割を演じているものと考えている.

84. Pancreozymin-Secretin Test 施行時の Immuno-reactive Insulin, Triglyceride, NEFA 值の変動について

山口大藤田内科 ○久保 勝彦, 竹中 俊助, 甲嶋 博明, 神山 俊彦 我々は，膵外分泌機能検查として，Pancreozymin-Secretin Test (P.-S. test) を採用し既に60余例の経験 を有しており，糖尿病，勝，肝，乃至胆道疾患患者において臨床上，幾多の有益な指針を得ている．今回の 報告は，糖乃至脂質代謝にしめる膵の主要な役割に稽み， P.S.刺激時における I.R. Insulin, TG 及び NEFA の変動を検索したのでての結果につき述べる，なお対象は，膵，肝，胆道疾患，糖求病患者等，20 例である. (i) 肝硬変症及び胃癌再発例の各 1 例に I.R. Insulin の增加がみられたが，大部分は変動がな かつた。(ii) TG の変動に一定の傾向はなかつたが家族性本態性高 TGR 患者の TGR は減少した. (iii) NEFA の有意の減少を示すものが 5 例あつたが，てれは I.R. Insulin, TG の動きと独立しており興味深い. 85. ヒトならびに家鬼の血漿インスリンおよび NEFA におよばす Xylitol 静注の影響

九大勝木内科 小串 俊雄, 藤沢 正二, 平田 幸正

5 炭糖である50\%キシリトールをヒトに $20 \mathrm{~g}$ および $30 \mathrm{~g}$, 家鬼も $1.0 \mathrm{~g} / \mathrm{kg}$ の大量投与した時のインスリ ン, NEFA 血糖を測定した。インスリンはヒトにおいては $20 \mathrm{~g}$ を 2 例に静注したが，いずれの例も軽度の 上昇を示した. $30 \mathrm{~g}$ を静注した時は， 3 例中 1 例に中等度の上昇を見たが，他の 2 例は軽度であつた。家鬼 においては非絶食時，24時間絶食時のいずれの場合にも高度のインスリンの上昇を示した。 上昇の程度は非 絶食時の方がより高度の上昇を示し，ブドウ糖を同量負荷した時とほぼ同程度であつた。 NEFA はヒトた おいては $20 \mathrm{~g}$ 静注時は低下を示した. $30 \mathrm{~g}$ では 3 例中 2 例に上昇を見たが大量負荷による精神的影響が関与 しているのではないかと思われる，血糖はヒトにおいても家鬼においても軽度の上昇を示した，以上の実験 より, キシリトール大量静注によるヒトのインスリンの上昇の程度は個体差があり, 家鬼においては高度の インスリンの上昇を来たした。 NEFA とヒトに $20 \mathrm{~g}$ を静注した時, 家鬼に $1.0 \mathrm{~g} / \mathrm{kg}$ を静注した時は低下を 示し，ヒトに30 g を静注した時には上昇を示した。血糖はヒトおよび家鬼いずれの場合にも軽度の上昇を示 した.

86. Cortisone の血中インスリン及び喏ラ氏島に及ぼす影響

京府医大吉田内科 吉田 秀雄, 横尾 定美, 奥村賢太郎, 進藤 俧三, 阿部 信行 阿部 敦, 藤井 正道, 木村 浩久, ○飯田 優, 油谷 桂朗 河野勝之裕

糖尿病の本態に関する研究の一環として, 今回はステロイドホルモンの血中インシュリン及び膆ラ氏島に 及ぼす影響について行なつた。正常成熟家鬼 4 匹に Hydrocortisone succinate $10 \mu \mathrm{g}$ 筋注を 2 週間, $20 \mathrm{mg}$ 筋注を続いて 2 週間, 内 2 匹を屠殺後, 残り 2 匹に Hydrocortisone acetate $10 \mu \mathrm{g}$ 筋注を 3 週間続いて行 
なつた． 4 匹の家鬼の血糖及び血中インシュリンの平均值は，血糖は 4 週間後まではほぼ横ばい状態であつ たが，Hydrocortisone acetate に変更後急速に上昇した。 ILAによる血中インシュリンは横隔膜法, 脂肪組 織法共まだ血糖上昇の見られない 4 週後及び 1 週後に既に上昇が見られたが，後に下降傾向を示した．IRI はほぼ血糖に平行して漸次上昇していつた．抽出インシュリンは， 4 週後屠殺のもの， 7 週後屠殺のもの両 方共高値を示した．膵組織学的所見は， 4 週後屠殺のものは $\beta$ 細胞の軽度の脱顆粒を認めるに過ぎなかつた が， 7 週後屠殺のものは脱顆粒の他に，膵外分泌部分の導管の増殖，新しいラ氏島の形成，巨大ラ氏島の出 現等の所見を示した．以上よりステロイドホルモンを家鬼に投与すると，早期にインシュリンの生物学的測 定法の.上昇, 続いて血糖, インシュリンの免度学的測定法の上昇が見られた。膵組織学的観察では, 初期に は脱顆粒が見られたが，後に hyperactivity を示した。

質問：広島大第 2 解剖 谷沢 義弘 組織像で導管上皮より cortisone の投与によつてラ氏島が新しく 作られると解釈してょいか.

応答：京府医大吉田内科 横尾 定美 Cortisone 投与時の膵外分泌部は非常に強い影響をうけると思 われ，膵管の異常な增殖とその增殖部にアルデヒドチオン好染性の細胞がみられる．ラ氏島の母細胞につい てはいろいろ問題があるようであるが，上述の所見はラ氏島が導管上皮より出来うる可能性を示すあのと考 える。

質問：岐阜大早瀬内科：竹内 三郎 Hydrocortisone 投与で血糖上昇に先行してインスリン分泌の增 量があるとのととですが空腹時に測定すると，血糖不変であつてあ食後には過血糖ががあつて，インスリン は恐らくそれを介して反応していると考えられるがいかがであるか.

応答：京府医大吉田内科 奥村賢太郎 採血前10１2洔間は絶食にしたので，食䬲による影響はない。

質問：京大哚瀬内科 八幡三喜男 ステロイド投与開始 1 週間以内の観察は行なつたか。臨床例では, ステロイド投与開始間もない時期に，糖負荷に対するIRI の過剩反応が認められる.

応答: 京府医大吉田内科 飯田 優 1 週間以内の血糖及び IRI の追求は行なわなかつた。

質問：神大辻内科 馬場 茂明 Cortisone 投与期間中，経過を追つて，GTTによる IRI，ILA の反 応をみた方が，膵内分泌機能をみる上に好都合ではないだろうか。その成績があれば教示願う。

応答：京府医大吉田内科飯田 優 糖代謝の障害されたと思われた時期のGTTによる血糖及び IRI の追求は行わなかつた。

応答: 京府医大吉田内科 奥村賢太郎 糖負荷は今回は採血量が多い為行なつていない，以前 FILA のみ測定した時の成績では, Cortisone 投与前と投与後 $1 \mathrm{~W} 飞$ 於ける糖負荷の比較で, $1 \mathrm{~W}$ 後明らかなイン スリン過剩反応を認めた。

87. Gluco-corticoid の Insulin 放出に及ぼす影響について，ととに哺乳動物の micro-dissection を用いて

徳島大油谷内科 油谷 友三，尾上 久吾，松永 実，野瀬 富夫，小橋 邦維 藤中 真一, 山本 達雄, 松茂 知, 新居 友夫, 矢田健太郎 平野 勝

私達は, てれまで, microdissection によりえた膡ラ氏島で, 各種糖質, ホルモンの Insulin 分泌機構に ついて検討して来た。 今回，Hyperadrenocorticism における Insulin level の上昇の機序を知るため次の 実験を行なつた。正常，Cortisol 投与，副腎摘出各マウスよりえたラ氏島を用いて，Glucocorticoid の

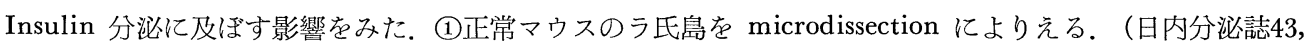
276, 1967) Glucose 300mg/dl を含むと，含まない medium に Dexamethasone (5.0,50.0, 1.0,10.0 $\mathrm{g} /$ $\mathrm{ml}$ ) 加えて, 120 分間, $37^{\circ} \mathrm{C} て ゙$ incubate し medium 中の Insulin を Radioimmunoassay にて測定し た。その結果いずれの場合も対照と比して，Insulin 分泌促進はみうれず. (2) Cortisol 5mg/day を2,5日間 
投与後のマウス. ラ氏島を, Glucose $300 \mathrm{mg} / \mathrm{dl}$ を含む medium で incubate して medium 中の Insulin を測定した. Cortisol 5mg/dl 5 日間投与では, Glucose による Insulin 分泌は促進された。. 次に Cortisol $10 \mathrm{mg} /$ day では，2,5日間投与共に Insulin 分泌は抑制された。 (3) 副腎摘出マウスを無処置群と Cortisol $2.5 \mathrm{mg} / \mathrm{day}$ 投与群に分け 3 日間飼育後のラ氏島を incubate して medium 中の Insulin を測定した. 共に Insulin 分泌は抑制された。. 以上より，Gluco-corticoid は，Glucagon 等による Insulin 分泌の如き 直接作用はない，ラ氏島 $\beta$-cell の酥素の合成に影響を及ぼすという説から，てのホルモンのラ氏島代謝に 及ぼす影響と Insulin 分泌とは何らかの関係をもつかもしれない. 故に Glucocorticoid は直接又は間接的 に Glucose に対する Insulin 分泌の感受性を増すと考学られる。

88. 二, 三の内科疾患における血中インスリン值の日内変動について

岐阜大早瀬内科 橋本 明憲，阿知波秀夫，近藤 靖士，今尾泰一郎，森 矩尉 竹内 三郎

糖尿病及び，その他二，三の内科疾患患者について糖質 $250 \mathrm{~g}$, 蛋白質 $70 \mathrm{~g}$, 脂質 $30 \mathrm{~g}$ の基準食投与下の 血中インスリン值の日内変動を免疫学的測定法により測定し, $50 \mathrm{~g}$ 糖負荷試験の場合と比較検討した。血中 インスリン值の日内変動は，乙れまでの糖負荷試験の場合の成績と，その傾向が一致する場合も多いが，ま た一方, 必ずしも一致しない場合もある.また, 症例により糖尿病治療薬服用中の日内変動で午前も反応し ているが，午後から夕方にかけて著明な反応を示すが血糖は余り低下しない例もあり，てのような例では血 中のインスリン効果の阻止因子も考えられる，ステロイド投与の比較的早期では，インスリン分泌進があ り, 長期に亘ると正常乃至低下して来る症例もあり, 治療中の薬凨効果と血糖調節の関係を伺うのに有利で ある. 以上血中インスリンの日内変動はインスリン分泌動態の理解に役立つものと思われる.

89. 抗インスリン血清注射による家鬼血中インスリン (IRI) の増大と, その生物学的活性について

九大勝木内科 平田 幸正, 藤沢 正二, 佐藤 八郎

IRI として測定される血中インスリンが，正常動物の血糖を降下させるか否かを検討した．まず正常家鬼 に, インスリン免度モルモット血清を静注するととによつて, IRI の著しく高い家鬼血清を得るととができ た. ただし，そのIRI の測定には，家鬼血清から酸性アルコールにて抽出する必要がある．次に，ての家 鬼血清中の IRI を集め, 正常家鬼に静注したととろ, 著明な血糖下降を認めた。 その例を示せば次のでと くである．まず，抗インスリン血清注射により，27,000 $\mu \mathrm{U} / \mathrm{ml}$ すなわち正常の約 1,000 倍の濃度を示すに至 つた家鬼血清 $60 \mathrm{ml}$ から, 酸性アルコールにて $10 \mathrm{ml}$ の抽出液をえた（抽出操作 2 回施行）。乙の抽出液のIRI 濃度は $93,000 \mu \mathrm{U} / \mathrm{ml}$ であつた。この $8 \mathrm{ml}$ すおち IRI として0.7単位を含む量を, 他の正常家鬼に静注し たとてろ，血糖值は前値 $90 \mathrm{mg} \% ， 30$ 分值 $60 \mathrm{mg} \% ， 60$ 分値 $43 \mathrm{mg} \% ， 90$ 分値 $57 \mathrm{mg} \% ， 120$ 分値 $63 \mathrm{mg} \%$ と著明 な低下を示した，以上から，血中 IRI として測定されるものは，正常動物の血糖值を低下させるものであ り，インスリンそのものである可能性が大きいといえるようである.

質問：京府医大吉田内科 奥村賢太郎 結合インスリンは抽出法により free となるが，その場合亦結 合しない前のインスリンと同じ活性を持つているのだろうか.

応答: 九大勝木内科 平田 幸正 結合インスリンは抗体とはなれれば, 再び生物学的活性を示すとい える.

質問：京府医大吉田内科 阿部 信行 AIS 注射後の家鬼より作成した IRI $0.7 \mathrm{U}$, crystalline Insulin 0.7 Uを静注した際両者の間に血楉降下に差があるか.

応答: 九大勝木内科 平田 幸正 抽出操作によつて, 結合したインスリンが遊離となつて, そてで测 定可能となるわけである。阿部氏に対し 血桾降下の最低値を来たす時間は異なつた。

質問：京府医大 吉田 秀雄 IRI が活性のあるインスリンそのものを測つているととを証明したとい わ机たが，IRI が大抵の場合インスリンを測つているととに異論はないが, インスリンの総てか, 又 IRI の すべてが活性かには尚問題がある。 
応答 九大勝木内科 平田 幸正 IRI がそのままインスリンそのものであるとはいえないが，少なく とあ活性を有するインスリンを測定しているといえる.

90. CGTT の一考察 一血中インシュリンの動きー

京府医大増田内科 葛谷 覚元, 森 克己, 入野 純一, 富川 純明, 中野 桂佑 白木東洋彦, 若松 健一, 加藤 甫明

$100 \mathrm{~g}$ ブドウ糖経口法による GTT, GGTT を施行し, 血糖, IRI 及び NEFA の変動を観察し, コーチ ゾンの糖代謝に及ぼす影響，更には Prediabetes の病態に関する若干の検討を試みた。対象を GTT の成 績から Fajans の基準で, normal (25例), Probable diabetes ( 5 例), diabetes ( 5 例) に分類し, 更に糖 疗病遺歴を有する者の中，GTT，GGTT 共に正常のものを Prediabetes（10例）として併せて観察した. 尚, 対象は全て空腹時血糖値は正常で, 肥満, 肝障害, 高令者等は可及的に除外した. CGTT の血糖, IRI, NEFA は, GTT に比べて, 各群共, その変動が著るしいが, 特に normal の中の GGTT 陽性群が, GGTT 陰性群に比べて血糖の著明な上昇，IRI の hyperresponse, NEFA の空腹值の上昇及び下降傾向 回復の遅延等が著るしく，より diabetic な変化がみられた。 また同じ GGTT 陰性者に於ても，遺伝歴を 有する所謂 Prediabetes と考えられる群では，遺伝のない normal 群に比し， IRI, NEFA 等の動きが diabetic な傾向を示した．乙れらの結果は，CGTT の意義及び，Prediabetes 病態を考える上に1つの示 唆を与えるものと考えたい. 即ち，コーチゾン投与により種々の変化がみられる原因の1つに，やはり本剂 の末梢に於ける糖処理能の障害作用を考えるべきで， Prediabetes を含めた初期糖尿病に於いてみられる上 記の変化は, Randle の云う Glucose-Fatty acid Gycle の機序から考えると甚だ興味深いものである.

質問：熊本大学体質医研 中村 専久 Prediabetes 群の中で NEFA 変動の異常と, IRI 変動の異常 が一致したのは何例あつたか.

応答：京府医大第三内科 若松 健一 Prediabetes に於けるIRI, の上昇は NEFA の normal に比 して Prediabetes に於て IRI 及び NEFA が normal 群より上昇したのは10例中 6 例に見られた.

質問：熊大体医研 三村 悟郎 私共も GGTT, PGTTをやつておるが糖尿症患者で PGTT が GTT より返つて良好となる場合が時々ある。すなわち GTT に比へて，PGTT が良好となる場合，古るいは悪 化する場合の IRI, NEFA の変動はどうなるものか御教示預きたい.

応答: 京府医大第三内科 葛谷 覚元 只今の御質問のような事実を吾々も個々の症例をみていると時 々経験している，しかし全体としての傾向では先程述べたような成績をえている。乙れに関しては更に症例 を重ねて検討中である.

91. 妊娠時における CGTT の検討

京府医大産婦人科 徳田 源市，水谷不二夫，上羽 至，木戸 敬 GGTT を介して弤娠中の糖代謝の実体を解明するため，GGTT の際の IRI NEFA について GTT と 比較し, 妊娠の経過を追い, 遺伝歴との関連も加え検討した. 遺伝歴については妊娠中, 特に後期に於て, GTT より GGTT で差は著明となる傾向が見られたが，Dittman の報告のように明らかではない，妊娠中 の GTT のIRI は CGTT 陰性群のCGTT のIRI は CGTT 陽性群, 又は probable diabetis の curve 亿似る. NEFA は空腹時は高值を示し, 回復の点では IRI の傾向と同じである。産裖では IRI は Hyper response を示すが，NEFA は正常となる. CGTT mechanism の解明につれ， cortisol が筋組織での phosphorylation をおさえ, glucose-transport を阻害することから, mild や, potencial diabetes では, peripheral machinary が cortisol に対し異常に sensitive となり, Insulin Hyper-response を生じると 云われている，妊娠中の NEFA，IRI から見ると，Randle らの，glucose-Faltyacid-cycle だけで説明が つくようであるが，産裖期の高血糖，IRI Hyperresponse にもよらず，NEFA は回復する点から，末梢 での phosphorylation の抑制, Glucose transport の阻害も関与していると考えられる。しかし妊娠中は胎 児えの Glucose の移行, 胎盤での Insulin 破壊の㠵進, 胎盤での lypolysis の尣進等の影響もあるので, この問題については, 色々な角度から，今後さらに検討を加えて，明らかにして行きたい. 
質問：神戸大辻内科 松岡 瑛 妊娠経過中に施行された GGGTに於てCGTT 陽性例分婏時, 或 いは新生児（例えば巨大児）の異常を認めた例を経験されたか.

応答: 京府医大産婦人科 木戸 敬 CGTT 陽性群は CGTT 陰生群に比べて巨大児出産, 妊娠中 経過，分婏異常等は特に差は認められなかつた。

92. Prediabetes の研究 一特に E.R.G. について一

熊本大体質研 宮尾 定信, 三村 悟郎，陣内 富男，橋口＼cjkstart純，定永 竹志 福島 敬祐, 坂本 安弘, 長崎 潮

我々は Prediabetes に関する研究の一環として，糖尿病家系者に対する E.R.G. の測定を行ない， N.E.F.A., I.R.I. 中性脂肪, 総コレステロール值等と比較検討をした. $50 \mathrm{gr}$ G.T.T. 正常の家系者28例中， 27眼に E.R.G. 律動様小波の異常を認め $(50 \%)$ 他の27眼は E.R.G. 正常であつた. 糖尿病者 33例中50眼 （約77\%） に，E.R.G. 律動様小波の異常を認めた. G.T.T. 正常の家系者に於いては，年令別，肥満度， NEFA, IRI に対しては, E.R.G. 異常との間に一定の傾向を見なかつたが，中性脂肪に対しては， E.R.G. 異常者に，中性脂肪の高い人が多く，E.R.G. 正常者に，中性脂肪が低いという成績を得た. 又同一家系者に 於ては，50gr G.T.T. が正常，異常にかかわらず，E.R.G. が高率に異常を来す家系と，高率に正常である 家系にわかれる傾向にあるという。きわめて興味ある成績を得た。

質 問：神大辻内科 馬場 茂明 Diabetic retinopathy の治療効果判定の規準にこの ERG が利用出 来ないだろうか.

質問：京府医大吉田内科 福井跾 ERG と血清トリグリセライドと関係があつたとも報告された が，糖尿病の罹病期間あるいは，それまでの糖尿病のコントロールの状態と関係があると思うがその点につ いて.

質問：阪大西川内科 島 健二 1 . 成績中に示された IRI 反応異常とはどういうあのか. 2 . 我 々のPrediabetes の実験に於いて糖負荷時の IRI 反応の買常として delayed Response として最初に現 われるが，先生の場合どうであつたか，3. 家系者の遗伝負荷の強さと IRI 反応の異常に何らかの相関関 係があつたか.

応答：熊大体医研 三村 悟郎 IRI の異常とは健康者に GTT を行なつた際の IRI の平均值+1 $\sigma$ 以上を異常と一応考えている，勿論 IRI の低值の場合も異常と考える場合ああるが，現在の所 GTT 時 の IRI の増加を Prediabetics の場合異常とみなして ERG, NEFA の変動と此較した訳である. また GTT 時の IRI のバターンの異常もある.

質問：京府医大吉田内科阿部敦 1) Prediabetes 中で比体重が肥満に傾く症例における NEFA, IRI, G.T.T., E.R.G. の内いずれが変異陽性率が高いか御教示願う. 2) 同上症例で，follow up された場 合，いずれか早く変異を打てして来るか御教預きたい.

応答：熊大体医研 三村 悟郎 糖尿病家系者のうちで, 肥満者の IRI と NEFA については, 155題 にて発表予定でる。すなわち NEFA の前值がやや高くGTT 後の NEFA の回復は正常体重者に比べて やや遅延する傾向がある．また GTT 後の IRI あ高值を示す傾向がみられる. Prediabetes の問題として， IRI P NEFA の異常が先行するか，あるいは ERG や㛑の生検によるような組織学的变化が先行するむ 極めて難しい問題である。この点を解明するため私共は現在臨床的実験的研究を行なつている所であり，今 後の検討にまちたいと思う.

93. Insulin 抵抗性糖尿病に関する研究

一第IV報一特に血中 Albumin 分画にみられる Insulin Antagonist について

$$
\begin{array}{rlrl}
\text { 神戸大过内科 } & \text { 过 昇三, 馬場 茂明, 松岡 瑛, 金子 滋夫, 高橋 洋介 } \\
& \text { 高石 務, 江原 成禎, 和田 昇, 竹下 通雄, 伊集院幸一 } \\
& \text { 小坂 欣也 } & &
\end{array}
$$

Insulin 抵抗性糖尿病の治療に際し蛋白分解酵素（ $\alpha$-Chymotrypsin, Pronase 等) を使用した場合，糖尿 
病状態の改善を見た症例はしばしば経験しその経過観察, 作用機序の解明と併せて Iusulin Antagonist に 対する各種解析を続けて来たが，今回は血中 Albumin 分画に見られる Insulin Antagonist の性格につい て検討した. Insulin Antagonist の力価算定には Davidson の Box method を使用し，ラット横隔膜で の糖利用を示標として行なつた, 又 Albumin の分離法としては, 正常人は Cohn 法, 糖尿病患者は Debro 法に従つて行なつた。 $3 \%$ Albumin では正常, 糖尿病共に Insulin Effect を阻害する作用は確かに認めら れたが，両者に差を認めなかつたので1\%に濃度を下げてみると正常 Albumin では Insulin 阻害作用は 認められず糖尿患者の Albumin のみに 3\%の場合よりはその作用は弱いが，やはり阻害作用を認めた。次 に Albumin を first Incubation のみに添加して細胞外に於ける影響見，他方 first, second-Incubation 共 に添加して Insulin 自体に対しての阻害作用を観察し，両者を比較したが，前者に於ける阻害作用は後者に 比して軽度で Albumin の Insulin 自体に対する阻害作用が細胞外に於ける作用より大きい様に思われた。 次に Albumin t Sephadex G-100 そて細分画し大きな蛋白分画順に I， II 分画と名付け更にII分画以後 に溶出した Sample を集めてXとし，ての各 Fraction を各々について実験を行なつた所，正常糖尿病共に I 分画には軽度の Insulin 阻害作用を認めたのみであつたが，II及びX分画では双方共明らかに Insulin 阻害作用を認めた。

質問：京府医大吉田内科阿部敦 1) 抽出アルブミンのIRIについて，2）抽出アルブミンに basal uptake を更飞抑制する antagonistic action があるだろうか. 3) Sephadex G100にて insulin antagonist を抽出アルブミンから分離しうるのか.

応答：神大辻内科 和田昇 (1) IRI は測定していない。 (2) スライドのけに出ているデーターは First Incubation と Second Incubation における Glucose uptake の差を出しているので Second Incubation の Glucose uptake の方が First incubation の Glucose uptake より大きい場合にはけのデータ 一が出る. (3)琴在の所 Insulin Effect を阻害するすのが Albumin 自身であるのか又は Albumin と一緒, 何か他のむのがあつてそれが Insulin Factor を阻害する Factor であるのかわからない.

応答：神大过内科 馬場 茂明 Albumin 分画を Sephadex にて細分画した各分画を Fr. I, II X と 名付けたが，Fr. X にはきわめて少い蛋白含量であつたが，電気泳動的にはAlbumin と同じ移働度を示 した。 又 insulin 効果も著明に抑制した。 との本態については visking tubingによる透折, 熱処理等によ つて蛋白部分と polypeptide 部分とに分けて検討したが，今の所結論に至つていない.

94. 肝機能不全随伴糖尿病の糖質代謝失調上における臨床特性

$$
\begin{aligned}
\text { 兵庫県立加古川病院内科 竹田 正次, 西川 和典, 三木 成孝, 藤井由紀子, O田中 一郎 } \\
\text { 高橋 }
\end{aligned}
$$

糖尿病入院 250 例中，本症該当例数 40 例 $(16 \%)$ であつた．本症を分つて 2 種類とし，(甲）糖尿病が重症 である場合，と（乙）糖尿病が中等症以下である場合，とに区分した。 40例中甲種15例，乙種25例。（Ｉ）甲 乙両種に共通した糖質代謝失調上の特性. (1) Tolbutamide 静注による血糖の態度は重症糖尿病群（恒久性 「イ必需群）において抵抗を示したが，本症群では軽症糖尿群でも抵抗を示す場合が少なくない．(既報)(2) $\lceil$ 1感性異常者が比較的多数（40例中17例約 $40 \%$ ）で，その内訳は，「イ」抵抗性糖尿病 7 例，「イ」反撥性糖 尿病10例であつた。 (3)本症では一般に「イ」の治効よりも，SU の方がその治効優良であつた．(4)腎におけ る尿糖排出閾值が高く，高血糖の割に尿糖の排出が少ない，(5)網膜症随伴者が比較的多数で40例中13例であ つた．（II）甲乙両種に相違した特性．(1)15例の甲種に属する症例中，2例を除く外は「イ」及び SU 治療 により全部中等症（軽症に近い）若しくは軽症に軽快するのを GTT 上で証明した。（2)乙種に属する25例 では比較的長期間の治療によるも，糖質代謝失調上の病態改善を認められない例が多かつた。

95. 糖尿病患者の血清ムコ多糖体及び N-acetyl- $\beta$-Glucosaminidase 活性に就て

熊大体医研成人体質学研究部 宮尾 定信, 三村 悟郎, 内田 乾爾, 飯田 一正

糖尿病患者 75例, 健康者58例について 血清中の蛋白結合総ヘキソーズ ( $\mathrm{PBH})$ ムコ 蛋白チロデン部分 (MPT) ムコ蛋白ヘキソーズ部分 (MPH) N-acetyl- $\beta$-Glucosaminidase 活性 (AGM) の測定を行なつた結果, 
MPT では殆んど差が見られなかつたが，PBH，MPH，MPH/PBH，MPH/MPT, AGM ではいずれも糖尿 病患者に高值を示す傾向が見られた。更に糖尿病患者について, 空腹時血糖, 眼底所見, 血清総コレステロ 一ル, 䍜病年数, 心電図所見, 尿蛋白, PSP 等との関係について検討し下記の結果を得た。空腹時血糖の高い群 が MPT, AGM は差がなかつたが他は高い傾向にあつた，網膜症を有する群が有しない群より MPH, MPH/ PBH, MPH/MPT, AGM で高くなる傾向が見られたが，網膜症進展の度合とは必ずしも比例しなかつた。 血清コレステロールとの関係では, PBH, MPH. MPT が高コレステロール群で高值を示す傾向にあつた. 罹病年数との関係では10年以上の群が未満の群より $\mathrm{PBH}, \mathrm{MPH} / \mathrm{PBH}$ で高くなる傾向にあり, 心電図所見 上 ST, T の変化を有する群が，そうでない群より，PBH，MPH, MPT, MPH/PBH で高い傾向を示した. 尿蛋白陽性群では，MPH， PBH，MPH/PBH，MPH/MPT が陰性群より高い傾向にあつた. PSP 15分值25 \%未満の群が以上の群より, PBH, MPH, MPT, MPH/PBH, MPH/MPT で高值を示す傾向にあつた.

96. 而糖曲線に対する内分泌的関与について

国立京都病院内科 ○赤沢 好温, 家原 利兼, 中山 志郎, 服部 譲 今日糖尿病の早期発見が重要視されるにつれて, 経口的ブドー糖負荷試験はその判定基準やブド一糖負荷 量に多くの議論が集中している. 然し GTT に対する内分泌的関与の問題も, Insulin や HGH の測定法 の開発によりその機序が明らかにされつつあるが，GTT は代謝的調節と内分泌的調節の総合的表現として その内分泌疾病における変動は興味をもたれている。我々は GTT と甲状腺機能六進症例の Mercazol に よる治療例の関係を追究し, 最高血糖値, 2 時間值, 3 時間値, 空腹時血糖值の速かな改善を言めた症例を 示し，Oxeyhyperglycomia 型のみならず，糖尿病型の GTT も状腺機能抑制と共に2，3時間值も速かに 正常化に向つた。 1 例において治療中 6 回の GTT を追究し, 先ず 3 時間値, 次に 2 時間値, 最高値の低下 を認め, 途中 Mercazol を中止して, 甲状腺機能が兄進すると共に 2 時間, 3 時間, 1 時間值の著增をみと め, Mercazol 再投与 1 力月において甲状腺機能抑制と共に 2 時間， 3 時間， 1 時間值の著明な改善を示し た. そして負荷後 3 時間值の改善が最も甲状腺機能の正常化と併行した. 更にネフローゼに Predonin, Abrnol を併用して GTT が糖尿病型を示した例において， steroid 中止後 2 週間で最高値， 2 時間， 3 時 間值は略正常化した。 又褐色細胞腫の 1 例に副胃腫摘出前後の GTT を比較し, GTT は術後速かに正常 化し, TBS は一時 $50 \mu \mathrm{g} / \mathrm{dl}$ と低血糖傾向を示し後正常に戾つた. 更に Acromegalia の 2 症例にて GH 高 值例（20倍）が軽度増加例（5 倍）より GTT の悪化は少なく, GH と併行しない. 又 Cusking 症候例 の手術前の GTT を示し, GTT に対する内分泌関与の複雑さを示した.

97，98. ホルモンと肝酵素 第一報および第二報

和歌山医大溝口内科 溝口 輝彦, 野本 拓, 石田 一哉, 御前千鶴子, 栗生 進 田中 豊, 岩橋 詨治, 黒田 弘, 上田 卓也, 中牟 田健 角田 博美, 戸田 㪍吾

ホルモンの肝代謝に及ぼす影響をみる目的で Wistar 系雄性ラットを用い. 下垂体摘除（以下下摘）副腎 摘除 (以下副摘) 膵亜全摘除 (以下膵切) およびそれぞれに AGTH, Glucocorticoid, Insulin を replase した際の肝酥素活性を mitochondria (以下 mito.) と mito. 外 Fraction にわけて測定した. mito. 外 Glyceraldehyde-3-phosphate dehydrogenase は Insulin によりかえつて活性低下し, Acetyl CoA carboxylase, Citrate cleavage enzyme, mito. 外 $\alpha$-Glycerophosphate debydrogevase などは Insulin により 活性増加し, 従つて Insulin は mito. 外では脂酸生合成, Triglyceride 生成促進するものと思われるが ACTH, Glucocorticoid は mito. 外ではこれら測定酵素活性に著変を与えなかつた。ところが mito. の酵 素で直接水素を electrone transport 系に受渡す NAD-Isocitrate dehydrogenase, Pyridine nucleotide trashydrogenase, NAD, Cytochrome G reductase, Glycerophosphate dehydrogenase などは下摘，副摘 などで異常活性増強を示しそれらに ACTH, Glucocorticoid を replase すると正常に復するととを知つた。 このととは下摘，副摘により electrone transport が即ち内部呼吸が異常に充進しているととを示してい る.そてで下摘，副摘およびそれぞれに AGTH，Glucocorticoid を replase した際の肝 mito.の ADP/0 
を酸素電極を用いて測定したととろ，下摘，副摘 ADP/0 での低下を，AGTH， Glucocorticoid のReplasement がそれを正常化させることを知つた. 以上のととより Glucocorticoid は少くとも Insulin の存在下 で electrone trasport とATP 産生との couple を正常化させるに必要なホルモンであると考える.

質問：阪大阿部内科 王子 亘由 Electrontransport に関係する enzyme 例えば Malic dehydro genase or $\alpha$-glycero phosphate-dehydrogenase が nutritional な影響をむ強く受けるが，との点について 何か知見あれば招教え預きたい.

質 問：北野病院 植手 鉄男 Reverse electron transport については如何.

応答 和歌山医大溝口内科野本 拓 (1) electrone transport の逆方向への移行が下摘, 副摘で起 つているのではないと思う。というのは下摘, 副摘で NAD Isocitrate dehydrogenase, Transhydrogenase NADH Gytochrome G reductase など Gytochrome 系に electrone を直接 transport する Enzyme 活 性が非常に六進していることからわかる。(2)下摘あるいは副摘でおこる nutritional な変化が酵素活性を変 化させたのではないことは，一般に栄養の低下は酵素活性を低下させるが私達の実驗で取上げている酵素活 性は異常增加を示しているである。

99. Insulin の Glucokinase 誘導におよぼす Steroid hormone の影響について

岐阜大早瀬内科 竹内 三郎, 森 矩尉

Cortisol は Insulin Antagonist の一つとして注目されているが，今回我々は肝 Glucokinase（以下 GK と略す）の Insulin による誘導に Cortisol が拮抗作用を示すか否かを in vivo で検討した。動物はウイ スタ一系白鼠を用いて, alloxan 動物或いは alloxan 動物に副腎摘出したものを作成し，それぞれについて Insulin 投与を加えた場合と, Insulin に Cortisol を併用したものについて肝 GK 活性を比較した. 肝 GH 活性は alloxan rat で著減するが，Insulin 投与で復活が見られる．正常動物に Cortisol 投与にて有 意の GK 活性の上昇を認め，乙れに Insulin を加えると更に著明となる. alloxan rat に同様に Cortisol を投与すると alloxan 単独の場合より更に活性值の低下を示し，血糖值の著しい上界を示す。この事より Cortisol 投与の場合の GK 活性の上昇は，膵 $\beta$ 細胞の Insulin release の交進を介しているものと考える. 次に alloxan 処置動物に副腎摘出し, endogenous の Insulin と Cortisol 欠乏動物では GK 活性低下を 認め，乙の様な処置動物に Insulin を投与すると活性の復活が見られたが， Insulin に Cortisol を併用し ても Insulin による GK 活性の上昇を阻害しなかつた. Cortisol は Insulin による GK 誘導効果には拮 抗的には働かない.

100. In vitro に於ける Cortisol の糖代謝抑制作用について（第一報）

名大日比野内科 松井 信夫

In vitroに於いてホルモンの生物学的活性を鋭敏に捉える事はホルモンの生理作用を追求するのに極めて 重要である. Overell 等は Mouse ear strip による糖の捸取が in vitro の微量の cortisol によつて抑制 される事を報告した，私はこの方法を改良して $\mathrm{G}^{14}$-Glucose の mouse ear strip による代謝を指標として Cortisol の作用をより鋭敏且高い精度を以つて捉え得たので，ての方法を用いて Cortisol の糖代謝に対す る作用を検討し次の様な成績を得た. 1) Glucose-1-Garbon (G-1-G 以下同様に略す) の $\mathrm{CO}_{2}$ 及び Fatty acid (FA) への代謝は Cortisol 0.0013 0.13 $\mu \mathrm{g} / \mathrm{ml}$ の濃度において，その濃度に平行した抑制を示した.

2) G-1-C, G-2-G, G-3.4-G 及び G-6-G の $\mathrm{CO}_{2}$ 及び FA への代謝を比較すると， $\mathrm{CO}_{2}$ への代謝は G-3.4G に於いて最高で G-6-G に於いて最低であり, FA への代謝は G-6-G に於いて最高で G-3.4-G に於いて 最低であり，G-1-C と G-6-C との FA への代謝の比は2：3であつた Cortisol は之等全ての Carbon の $\mathrm{CO}_{2}$, FA への代謝を抑制した. 3) G-1-G と G-6-C との Glyceride-glycerol 及び Glycogen への代謝は 大体同じ程度で, Cortisol は夫等を同程度に抑制した．以上の結果から Cortisol はその生理的濃度に於い て Glucose の代謝の全ての主要な径路を抑制する事が明かで，ての事は Cortisol の作用点が Anerobic glycolysis の初期にある事を推定させる.

101. In vitro に於ける Cortisol の糖代謝抑制作用について（第 2 報） 
名大日比野内科 松井 信夫 糖代謝の中間代謝産物に対する Cortisol の作用を検索する事は Cortisol の糖代謝自体隹対する作用機作 を知る上に重要な手懸りを与えると思われる。にててで私は前題と同様の方法を用いて Pyruvate と Glucose6-phosphate (G-6-P) の $\mathrm{Co}_{2}$ 及び Fatty acid (FA) への代謝とそれに対する Cortisol の影響を観察したの で報告する．1) Pyruvate-1-Carbon (P-1-G 以下同様に略す) 及び P-3-G の $\mathrm{CO}_{2}$ 及び Fatty acid (FA) への代謝は Cortisol により軽度に抑制される。然し乍ら medium 中に glucose を添加すると Pyruvate Carbon の FA への代謝は著明に増加し，乙の代謝は Cortisol によつて強く抑制される，2) G-6-P の $\mathrm{CO}_{2}$ 及び FA への代謝は Cortisol によつて明かな抑制を受ける. 3) G-1-G ${ }^{14}$ と G-6-P-1-G ${ }^{14}$ との Glucose medium における代謝の態度の差とそれに対する Cortisol の抑制の差から G-6-P は細胞外に於て Glucose と phosphate とに分解される事なく組織に利用されると考えられる. 上述の結果から Cortisol の 糖代謝住対する作用は Anerobic glycolysis の Pyruvate 亿到る径路より前の段階に働くと考元られ， Cortisol の Lipolysis や Gluconeogenesis に対する作用の二次的な影響ではない事が推定される. 又 G-6P 及び Glucose の代謝が共に Cortisol によつて抑制される事は Cortisol が Glucose の phosphorylation mechanism に㗢くものでない事を示す．以上の結果を綜合して Cortisol の Glucose 代謝に対する作用点 は細胞膜の Glucose transfer mechanism にある可能性か漒い事が推定される。

質問: 北野病院 植手 鉄男 Cell membrane の Glucose への透過性に Cortisol が作用されるもの と考えるが, Homogenate で実験を行なわれたか.

応答：名大日比野内科松井信夫 1) Homogenate を用いて実験した事はないか。2) medium に albumine を使用した実験は他の目的でやつた事がある。この際 albumine を使うと cortisol の抑制作用 は albumin を使用しない場合より低下する。これは Cortisol の Albumine との結合による不活性化の為 と思う. 3) Glucose-6-phosphate は細胞外で hydrolysis をうけずにそのままの形で利用されと考えられる。

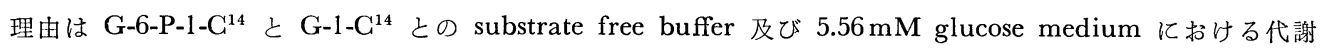
の差及びそれに対するCortisol の作用の差から推定した。

102. 甲状腺機能立進症と糖代謝について

鳥取大浅越内科 浅越 嘉威, 安部 喬樹, 小笠 原担, 山崎 弘巨 甲状腺と糖代謝の密接な関連は古くより知られており, 甲状腺機能立進症にしばしば糖尿をみることもよ く知られている.しかしながら, 甲状腺機能宁進症が長時間続いたため, 膵に著明な変化をきたしたという 報告はまだなく，脳下垂体，副腎皮質に比べて，糖尿病における甲状腺の意義は少ないと考えられている. われわれは最近, 甲状腺機能え進症の経過中に真性糖尿病を発生した症例を経験した。乙れを単なる合併と みるかどうかは問題だが，15年間の甲状腺機能立進症の経過中，比較的よく糖尿，あるいは血糖の推移を観 察し得たもので, それによると甲状腺機能六進症による過血糖状態がながく続いた結果, 膵ラ氏島の永続的 機能低下をきたしたのではなからうかの疑がつよい，そてで甲状腺機能元進症60例の GTT, PGTT トルブ タマイド負荷試験の結果を検討し，真性糖尿病パターンを示すものが，11.6\%にみとめられた．そのような 状態が長期間持続すれば，その結果として真性糖尿病を惹起するという考え方は否定し得ないと思われる.

103. 肝 Phosphorylase 活性に対する Hormone の相関について

岐阜大第二内科 伊東 毅, 竹内 三郎

（目的，方法）糖原分解をつかさどる Phosphorylase 活性は種々ホルモンの影響を受けやすい，今回は 正常動物に対するグルカゴン，アドレナリン投与の影響を観察すると共にさらにアロキサン糖尿動物，アロ キサン糖尿副腎摘出動物に甲状腺ホルモン, 副腎皮質ホルモンの投与をおてないそれぞれの肝Phosphorylase 活性を測定しその変動を観察して正常動物に対する影響と比較し本醉素活性を支配するホルモンの相関につ いて検討をおてなつた（成績，結論）グルカゴンとアドレナリンの効果を比較すると血糖值は上昇の時間 的なずれはあるが明らかな差はなく，糖原含有量はグルカゴンで早い時期に減少しその後回復，增加の傾向 を認め, アドレナリンでは減少を示し回復がおそかつた。肝 Phosphorylase 活性值は両ホルモン共上昇を 
示したがグルカゴン投与における長時間の活性上昇にもかかわらず肝糖系の増加を認めての時期の糖原合成 の促進因子の介存が考学られる.コルチゾールの影響は正常動物でのみ活性上昇しアロキサン糖尿動物で上 昇を認めない点より一部は $\beta$ 細胞を介して作用する可能性を想定した。 $\mathrm{T}_{4}$ の影響は正常，アロキサン糖尿 動物で活性上昇を認めての上昇作用は $\beta$ 細胞には関係なくアロキサン糖尿副腎摘出物で上昇が確実でない点 より考光一部副腎を介して作用していると思われた。肝 Phosphorylase 活性は一部ホルモンの直接の影響 を受けるが又一部は二次的に他のホルモンの影響に支配され生体糖調節に関与するものと考えられる.

104. 電解質と糖代謝に関する研究 第 3 報 無機燐

大阪莪信病院第 1 内科 石上 隆一, 塩谷 茂, 吉田 著, 河田 利延, 名取 弘道 秋山 喜昭, 大本 潤子, 岡田 博行

大阪鉄道病院第 1 内科 閒田一郎

糖負荷を行なつて血清 $\mathrm{K}, \mathrm{Mg}$, 無機燐（以中 $\mathrm{P}$ 之略）の変化を追求した。いずれも健康者では著減した が, 糖尿病患者では殆んど变化がなく, 肝疾患患者, サイアサイド（以下サと略）糖尿患者ではやや減少し た．乙の傾向は $\mathrm{K}, \mathrm{Mg}$ ，に比較して $\mathrm{P} か ゙$ 軽度であつた，血清 $\mathrm{P}$ は昏睡を除いた糖尿病患者では減少してい る者もあつたが，ほほ正常であつた，サ糖尿患者では減少している者が多かつた，しかしサ糖尿患者では血 清 P の減少と耐糖能の低下とは血清 $\mathrm{K} の$ 如く必ずしも相関しなかつた。 サ糖尿患者にK萫を投与すると血清 $\mathrm{K} の$ 正常化と共に耐糖能も改善したが， $\mathrm{P}$ 薬を投与すると血清 $\mathrm{P}$ は正常化したが耐糖能の改善を殆んど認め なかつた， $\mathrm{P}$ 欠乏動物は $\mathrm{K}$ 欠乏動物に比較すると, 耐糖能の低下したものが少く, その程度も軽度で, 膵 $\beta$ 細胞の顆粒の変化も著明でなかつた. 要するに $\mathrm{P} も$ 糖代謝に関係があるが, サ糖尿の発生機転として, 低 $\mathrm{K}$ 症は要因であるが, 低P症は要因と考えられない.

105. 膵ラ氏島ホルモンの生成と放出に関する研究(第 7 報)絶食家鬼のラ氏島の変化について 京府医大吉田内科 吉田 秀雄, 横尾 定美, 青地 脩, 内藤三樹郎, 松野 瑞賢 木村 敬, 藤井 正道, 木村 浩久

ラ氏島ホルモンの生成と放出に関する研究の一環として, 前回に引続き, 絶食家巵を用いて光顕並びに電 顕的観察を行なつた。絶食 3 日目では, 正常に較べ Aldehyde-thionine 染色性が減少し, 電顕所見でも, $\beta$ 顆粒の減少, Golgi 野の縮小がみられる。絶食11日目では, ての所見は更に著明になり, inactive stage を思わす発達の悪い Golgi, Lysosome-like body の出現がみられる，我々は，更に11日間絶食後，3 日間 含水炭素豊富食を与えた家鬼ラ氏島の細胞の動きを観察したが, Aldehyde-thionine 染色性が増加し, 電顕 所見では, $\beta$ 顆粒の増加, 発達した Golgi 野, mitochondria の密集像がみられ, 細胞は正常に復している ことが考朰れる．尚何れの時期にも core を持たない顆粒限界膜が見られる．てれは $\beta$ 顆粒が diacrine 型 式によって放出せられた後の残存顆粒膜と考光られる。尚, 家鬼 $\beta$ 細胞でみられる filament の消長は inactive stage ほど少いように思われるが，確定的な事は言えない。

質 問 : 広島大学第 2 解剖 谷沢 義弘 1）今までの研究でのコウモリ, 蛙等で絶食によつて $\beta$ 顆粒が 增加するというデーターと先生の結果との差はどのようにお考えか.

応答：京府医大吉田内科松野瑞蜸 (1)絶食 3 日目では著明な変化をみないが, starved 状態に長く 放置しておくと inactive となり, Insulin demand がないので, 顆粒は余り残存しないと思われる。(2) $\alpha$ 細胞の增大からみられるが，個々の細胞の stage が幾分違うためか， $\beta$ 細胞のアルデヒド・チオニン染色 性が拈ちてみられるあのあ多数ある.

応答: 京府医大吉田内科 横尾 定美 チオニン染色性という言葉の意義であるが, 絶食家鬼ラ氏島で は, 同一ラ氏島内で染色性の低下している $\beta$ 細胞が多いという意味で, チオニンによく染る $\beta$ 細胞も混在し ているととは御意見の通りである.

106. 膵ラ氏島ホルモンの生成と放出に関する研究（第 8 報）

一ラ氏島の螢光顕微鏡所見を中心として一

京府大吉田内科 吉田 秀雄, 横尾 定美, 青地 脩, 内藤三樹郎, 松野 瑞賢 
木村 敬, ○藤井 正道, 木村 浩久

膵ラ氏島ホルモンの生成と放出に関する研究の一環として, 各種条件下のラ氏島の螢光顕微鏡所見を中心 として観察した．材料は総て家鬼を用い，無水 Alcohol-20C 4 時間固定によるパラフィン切片法で作製, 反応は間接法 (サンドウイッチ法) によつた. 非標識抗血清による blocking test 及び NGPS による対照 試験を行なつて螢光陽性物質の特異性を確認した。総ての実験条件を同一にはできないので，所見としては， 螢光の有無, その特異性状のみを問題にした。（結果） (1)正常家匝一ラ氏島中央部の $\beta$ 細胞に一致して diffuse 且つ均等な発色を有する螢光陽性細胞を認む。（2) 絶食—3 日目では正常と变わらず，10日目では 中央部に螢光陽性細胞の減少が認められた。(310\%ブドウ糖点滴中—4 時間目の高血糖持続時でも正常と 比し大差ない所見を得た. (4) AIS $3.0 \mathrm{cc} / \mathrm{kg}$ 投与— 2 時間目の急激な血糖上昇期には, 光顕で $\beta$ 細胞のや や著明な degranulation と margination のみられるのと一致して螢光陽性細胞のかなり減少と残存せる螢 光の不均等性が認められ，4 時間後の血糖最上昇期では, 上述の変化が更に進み, 螢光陽性細胞が極めて減 少した. (5) Alloxan $150 \mathrm{mg} / \mathrm{kg}$ 投与一 6 時間後の低血糖期には, 螢光は萎縮した $\beta$ 細胞の周囲にのみ限 局，4 日後の高血糖期には，ラ氏島内の螢光陽性細胞は消失乃至点在するにすぎなかつた（結論） 以上の 所見等から考えて, ラ氏島 $\beta$ 細胞の諸種変化を知る上で, 螢光抗体法も光顕, 電顕等と共に有効な手段であ ると考党られる。

107. ヒナおよび鶏胚ランゲルハンス島 $\mathrm{D}$ 細胞の電子顕微鏡的研究

京府医大第二解剖 町野 満夫, 佐久間 宽

5〜20日孵卵，3，5，7日ヒナの膵蔵を摘出し, glutaraldehyde, osmic acid 固定, 脱水, epon 包埋を行 なつた. porter-Blum microtome にて超薄, 切片には lead citrate 染色を施して HU-11A type の電子顕 微鏡で観察した．D細胞は low moderate electron density の円形〜卵円形の顆粒（直径 150-650m $\mu$ ）を 有していて, 容易に A 細胞, B 細胞と区別出来る。顆粒は限界膜に包まれて, 顆粒と膜は大体密に接してい る．乙れらの顆粒は血管に近い細胞質に集積する傾向がある．Golgi 装置は発達して，顆粒の形成像をしば しば示す. 小形の糸粒体, 系状の粗面小胞体, 中心小体, リボゾームが見られる。まれに, 中心鞭毛が細胞 間隙に突出する．躬卵13日以後，血管に面した細胞膜にはしばしば，顆粒が接近して，顆粒の限界膜と細胞 膜は癒合している．また顆粒と同じ直径を持つた浅い凹みや，短管状の凹みを示す．ての凹みの中には細胞 内の顆粒と同様のものが見られる．乙れらの深浅の凹みは他の分泌細胞でも報告されているように，単一あ るいは複数の分泌顆粒の放出を暗示するものである (Lacy 1961 ; Kurosumi 1961 ； Ichikawa 1965). D細 胞の機能は不明であるが，今回の実験によつて，embryo の stage からD細胞は分泌を行なつているととが 形態学的に明らかになつた。

質 問：広島大第 2 解剖 谷沢 義弘 フラン 5 日で $\mathrm{A}, \mathrm{B}, \mathrm{D}$ 細胞の 3 種類とも見られたか.

応答: 京府医大第二解剖 町野 満夫 1) 見られる. 文献上はフラン 3 日から現われるといわれる.

質問・京府医大吉田内科松野瑞賢 (1)D細胞の同定はどのようになされたか。(2)D細胞の頻度はど の程度加。

応答：京府医大第二解剖 町野满夫 1) 光顕的にはD細胞は特異に染色出来る。例えばマロリー, アザン染色をすると pale に染まる。電顕的には，Alpha 分泌顆粒は非常に電子密度の高いものであり， Bata 分泌顆粒は結晶様である。一方 delta 分泌顆粒は電子密度がほぼ constant に低いもので容易に分別 が出来る．2）頻度について測定したととはないが，割によく見られる。

108. Insulinoma におけるインスリン分泌機序について

阪大阿部内科 繁田 幸男, 中村 幸二, 康 敏煥, 井上 通敏, 荒木 躋 阿部裕

私共は最近 Insulinoma 2 例を経験したが，この中症例 1 は低血糖症状の発現頻度か稀なものであり，症 例 2 は殆んで毎日空腹時に重篤な低血糖症状を招来したものである．かかる 2 症例におけるインスリン分泌 機序について種々検討を加えたのでててに報告する，症例 1 は, 空腹時の血糖インスリン (IRI) は高值を 
示すと共にブドウ糖, Tolbutamide, L-Leucine を各々投与した場合いずれも血清 (IRI) の上昇がみられた が，特にブドウ糖に著明であり，Tolbutamide と L-Leucine はほぼ同等であつた。 また腫瘍部を含む膵約 $2 / 3$ の切除により各々のインスリン分泌の程度は, いずれも術前より著しく低下し正常化するのか認められ た. 症例 2 も空腹時の血清 RI は高值を示したが, ブドウ糖を約 5 時間静注した場合, 血清 IRI はこの間 きわめて恒常的な值を認めた．乙のととは Insulinoma が本例のように組織学的に良性の腺腫であれば，イ ンスリン分泌の態度は正常と同様に自律性がなく，ただ正常よりも基礎分泌と種々の刺激による response が過大である。とが特徵的といえよう．次にブドウ糖静注後の血清 IRI の上昇はアドレナリンまたは $\beta$ blocker である Propranolol の投与により殆んど完全に抑制されるが，グルカゴン筋注後の血清 IRI の上 昇はアドレナリンないし Propranolol の投与によつても抑制されなかつた．以上の成績は Insulinoma に おいても正常と同じくブドウ糖およびグルカゴンの分泌機序が異なるととを示すものである.

109. 膵亏氏島腺腫の 1 例

岐阜大乾内科 乾 成美, 野手 信哉, 時光 直樹, 安藤 成人, 永田 和夫 端山 和雄, 林茂弘, 吉田 健生

43才男. 約10年前より時々発作的に意識混濁を来すようになり，8 年前からこの発作が空腹時に起り，糖

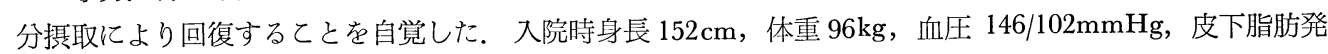
育良好で腹部は著明に膨隆しているが，皮膚，心肺，四肢等には異常を認めず，意識混濁時の血糖值は $35 \mathrm{mg} / \mathrm{dl}$ と著明な低血糖を示し, glucose 負荷後も最高 $90 \mathrm{mg} / \mathrm{dl}$ であつた. 一方, 空腹時血中 insulin 值 (Hales \& Randle 法) は $115 \mu \mathrm{U} / \mathrm{ml}, 50 \mathrm{~g}$ glucose 負荷60分後には $500 \mu \mathrm{U} / \mathrm{ml}$ 以上とともに異常な高值を 示した. atropin, L-leucine および tolbutamide 試験で著明な血糖低下を, adrenaline, prednisolone 試験 で血糖上昇を示した，尿 17-KS 分画で 11-oxygeneted 17-KS の減少を認め， RISA を用いた albumin

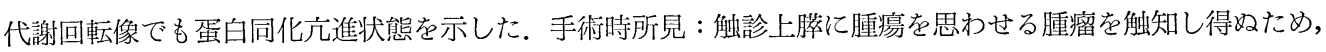
ラ氏島細胞の過形成と考え，尾部 $2 / 3$ を切除した。 なお，術後 24 時間にて死亡，剖検にて膵頭部に大きさ 2.0 $\times 1.5 \times 1.5 \mathrm{~cm}$, 重量 $3 \mathrm{~g}$ の腫瘍を認め, 組織学的にはその細胞は島細胞に類似し, Gomori 染色で核は淡黒 色に染り， $\beta$ 細胞と思われたが，細胞の異型，核分裂，核異染性はなく結合織により被包化され，正常組織 とは明らかに区分し得た良性膵ラ氏島腺腫であつた。

質問：座長 京大外科 本庄教授 術中血糖値を測定されながらやられたか.

応答：岐阜大乾内科 吉田 健生 術中. Glucose の点滴静注をしていたが術中, 術後経時的に血糖値 の測定をし，膵尾部切除後血糖值上昇を認めて手術を終了した。術中は Hyperplasia と考えていたが後日 の剖検にて膵頭部に腫痬を発見した。

110. Insulinoma $\beta$ 細胞の電顕的観察

阪大阿部内科繁田 幸男, 康 敏煥, 小浜 基郎, 井上 通敏, 森脇 健 阪大中央臨床検查科 竹田 繁美

Insulinoma 於てはインスリン分泌が生理的に必要とする以上に行なわれるものであり，インスリンの産 生, 細胞内での貯蔵および血流中への分泌を知る上に，好個な材料を提供している. 私共は最近 Insulinoma の 2 例を経験し, その腫瘍について光顕および電顕的観察を行なつたのでここに報告する. まず光顕像 (H$\mathrm{E}$ 染色）であるが，低血糖症状の軽度であつた．第1例は実質細胞と共に間質細胞が豊富であつたのに比し 比較的重篤であつた，第 2 例では間質細胞は乏しく，ほとんどが実質細胞で，かつ腺腔形成が著明であつた. Gomori AF 染色では, Insulinoma は正常 $\beta$ 細胞よりも染色性が低下していたが，第 1 例と第 2 例を比較 すると，第 2 例の方が染色性は優つていた．事実腫痬のインスリン含量は約 $6.7 \mathrm{U} / \mathrm{g}, 13.7 \mathrm{U} / \mathrm{g}$ で第 2 例に大 であつた．エポン包埋，ウラニール，鉛の重染色の電頸像では， Insulinoma は $\beta$ 顆粒の比較的多い細胞と 殆んどそれのみられない細胞から構成されているが全般的には，顆粒の乏しい細胞が多かつた. しかしその ような細胞に於いても細胞小器官 (organelles) はよく発達していた。 $\beta$ 顆粒の core（芯）はすべて円形で あり, 正常の $\beta$ 顆粒が多様性を示すのとは異なつていたが, core の周囲が unit membrane でとりかてま 
れているのは正常 $\beta$ 細胞と変るとてろがなかつた。 またミトコンドリアの中はは, 空胞形成のみられるもの もあつた，以上の観察から Insulinoma $\beta$ 細胞のインスリンはその作用, 細胞内での䝪臟および分泌型式 が正常 $\beta$ 細胞とは異なる可能性があると考える.

質 問：広大第 2 解剖 藤田尚男 1） $\beta$ 顆粒の放出様式は如何 2) Lacy のいった emiocytosis は認 められたか 3）私は $\beta$ 顆粒は diacrine 様式による分泌をする可能性があるように思うが如何 4）ただ polypeptide である $\alpha$ 顆粒が emiocytosis, 蛋白である $\beta$ 顆粒が diacrine 様式で出るとすれば不合理のよう な気もするので私自身迷つている。何か見解をおむちか

応答: 阪大阿部内科 小浜 基郎 (1)グルコース, 抗インスリン血清投与の動物実験の結果から考えて, diacrine 様式が主であると思っている. (2) $\beta$ 細胞に於ては, まだ認めていない. (3)私達も $\beta$ 顆粒は diacrine 様式で細胞外飞分泌される可能性が強いと考えている. (4) $\alpha$ 顆粒はグルカゴン, $\beta$ 顆粒はインスリンとされ ているが, $\alpha$ 細胞や $\beta$ 細胞内でグルカゴン, インスリンとして存在し眝蔵されている場合, 何かを結合し た状態(ポリマ)となり，流血中のグルカゴン，インスリンとは異なつた差があるのではないだろうか.

質問: 京大深瀬内科平川 敬二 正常の $\beta$ 細胞に比して, 多くの Free ribosome が認められたか.

応答: 阪大阿部内科 小浜基郎 1) Insulinoma の第 1 例, 第 2 例ともに free ribosome が豊富な 細胞や rough surfaced endplasmic reticulum の形で ribosome が存在している細胞など種々観察されて いる.

111. 消化性空腸潰瘍を繰返し剖見により, 膵, 副腎, 甲状腺に腫湯性変化を認めた 1 例

名大星川外科 鈴木 律夫, 根来 洋, 山岡 透, 古川昭八郎, 佐々木時三郎
仙石 光彦

胃濱瘍による胃切除後, 胃空晹吻合部に消化性潰瘍が発生し, その切除後にも消化管出血が持続し, 死亡 するに至つた患者の剖㒻にて次の如き所見を得た１１）愺藏頭部. 尾部に腫瘍を認め, 組織学的には細胞が リボン状，ロゼット状に配列した islet cell carcinoma であつた。そその他にラ氏島の Adenoma 様の hyperplasia が認められた。 2) 副甲状腺には diffuse な Hyperplasia が認められた。 3) 左副腎に Adenoma を

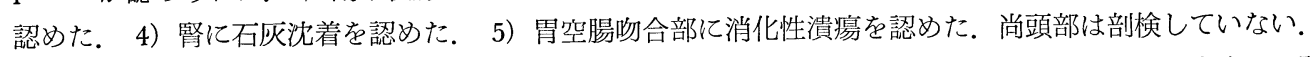
剖見所見より, 本症例が多発性内分泌腫と推定された。本症にしばしば合併する消化性潰瘍と, 本症との関 連性について文献的考察を加えた.

質問：京大深瀬内科 井上 博 (1) 4 個の副甲状腺の凡てについて検查したか. (2)尿路結石はなかつ たか.

質 問：岐阜大早瀬内科 竹内 三郎 ラ氏島細胞腫の細胞種類（ $\alpha, \beta$ の区別）は如何か.

応答: 名大第 2 外科 鈴木 健夫 (1)副甲状腺に関して 4 個の副甲状腺のうち 1 個丈について桧査し た。 (2)X線写真(骨), 輸尿管結石について X線はとつていない。輸尿管結石はない. (3) 膵腫嗙の $\alpha$ - or $\beta$-cell かの由来についてははつきり分らないが臨床的に Hyperinsulinismはなかつた。

112. 膵全剔糖尿犬における腸管粘膜の組織学的並びに組織化学的研究

京大外科 I 講座 本庄 一夫, 水本 竜二, 吉沢 雄二 膵全剔後の消化吸収機能検索の一環として腸粘膜の立場から特に脂肪吸収及び粘膜細胞自体の醉素活性を 追求し次の結果を得た. 組織学的には, H.E. Azan., PAS いずれの染色でも特に吸収障害を来す所見は認め なかつた．膵全剔インシュリン投与だけでは，絶食後においても尚吸収上皮時には中心乳ビ腔にも脂肪滴が 見られた。 又 Alkaline phosphatase, ATP ase 及び Sun DH の活性はいずれも低下の傾向を示した. し かし，Estrogen を併用すると，粘膜に残存していた脂肪滴は消失し，又低下した䤉素活性は，いずれもほ ぼ正常犬と同様に活性を保持した。膵剔インシュリン投与大では, オリーヴ油のみならずオレイン酸を投与 しても 2 時間後においてもその吸収像は認めなかつた。しかし Estrogen 併用犬ではオリーヴ油の吸収には 
影きょうを全く認めなかつたが，オレイン酸はほぼ正常大と同様な吸収像を示した. medium chain T.G. は, long chain T.G. に比し, よりすみやかに吸収され又その消失も早かつた．膵全剔インシュリン犬に medium chain T.G. を投与すると， 3 時間後に絨毛先端より僅が吸収されている像が得られた。 medium chain T.G も, その吸収において猝りパーゼの重要性が考えられる，以上の実験成績より，膵剔犬では，吸 収障㥂が明らかに存在し, 又粘膜細胞の alkaline phosphatase, ATP ase, Sun DH 等の活性低下は, Estrogen の併用でよく改善され, 従つて Estrogen 細胞内代謝を円滑にし, active transport に好影響を与光, 又燐脂質代謝を円滑にし，吸収が改善されるものと考える.

113. Human Corpus Luteum の Progesterone Synthesis に対する Gonadotropin の作用機序に関する in vitro 実験

奈良医大産婦人科 前山 昌男, 竹本 泰三, 土田 容子, 松岡 弘三 ヒト黄体の Progesterone synthesis に対する Gonadotropin (HGG) の刺激作用機序について実験を行な つた. (1) HGG, HMG, 及び LH (NIH•Orine-LH-SI) はヒト黄体 slice sincubation にて de-nero prog-

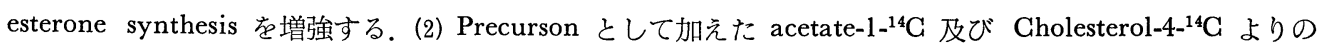
progesterone への ${ }^{14} \mathrm{C}$ のとりてみ」も增強する. 即ち gonadotropin は acetate 或いは Cholesterol よ り progesterone に至る合成経路を刺激する。(3) Gonadotropin は黄体 slice incubation にて progesterone synthesis を刺激すると同時に組織蛋白への labeled amino acid (Valine- $\left.{ }^{14} \mathrm{C}(\mathrm{V})\right)$ のとりとみも増加させる. (4)蛋白合成阻害剤 Cycloheximide (Naramycin) は(3)に観察された gonadotropin の作用を inhibit する. (5) gonadotropin の steroid genesis 亿対する作用機序は多面的である.

質問：阪大微研 須川 佶 1 . G 添加洔の Prog. 産生の增加がサイクロベキサミトロにより低下 する程度は， G添加を行ない実験例のレベルを越えるのか，2，G非添加実験例にサイクロヘキサミドの影 響を観察されたか， 3. 以上の質問の意味は, G添加時に Prog 生成が增加するのは, in vitro で incubation を行なつている間に, steroid 合成系の醇素蛋白の新生が促進されているかどうかの判断に可成り重大 な根拠を呈示してくれると思う。

応答：奈良医大産婦人科 前山 昌男 1) HGG (500 I.U.)+Cycloheximide $(1000 \mu \mathrm{g})$ 添加時の progesterone synthesis は HCG 非添加 cycloheximide のそれと殆ど同様である。2，G( 及仍び Cycloheximide 添加の slice における progesterone synthesis はG $($ で cycloheximide 非添加のそれと殆ど同様で ある， 3. 以上の成績より cycloheximide は endogenous に由来する slice 中の steroid 合成系の酵素活 性には no effect であり, 従つて incubation 中に gonadotropin によりての醇素蛋白の活性が阻害される という推論が可能である.

114. Human Placenta そおける Progesterone Synthesis に関する in vitro 実験 奈良医大産婦人科 前田 昌男, 土田 容子, 松岡 弘三 ヒト胎盤における Progesterone Synthesis について，12例の双胎々盤及び 1 例の品胎々盤を用いて in vitro 実験を行なつた。（1）胎艋の progesterone 含有量, 妊振末期 (last trimester) の胎盤 $1 \mathrm{~g}$ 当りの

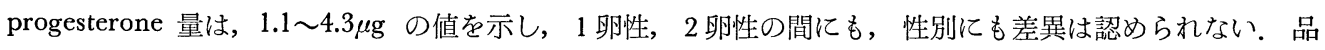
胎の胎盤では $4.2 \mu \mathrm{g} / \mathrm{g}$ であつた. (2) 3 例の双胎々盤において cholesterol-4- ${ }^{14} \mathrm{C}$ 及び prognenolone-4- ${ }^{14} \mathrm{C}$ を slice incubation したが, progesterone への conversion は, 夫々, $1.1 〜 2.6 \%$ 及び7.3〜14.0\%であつ た. しかし 2 例の胎船における acetate-1 $1{ }^{14} \mathrm{C}$ の incubation では progesterone への ${ }^{14} \mathrm{C}$ のとり込みは本 実験条件下では認め得なかつた（3） 3 例の双胎々盤，1例の正常半胎々盤について slice incubation に より de novo progesterone synthesis を測定したが, NAD, NADPH (NADP+G-6-P) の添加時には対照 に比して著明な増加を認めた。胎盤には母体及び胎児側より由来せる preformed precursor が多量に存在 するものと考えられる。

115. 家鬼卵巣に於ける Progestin 生合成に関する研究(4)

阪大第 2 病理 岡野 錦弥, 永井 清和, 松本 圭史, 虎頭 廉, 花井 淳 


\section{阪大遺伝 山根源太郎, $\bigcirc$ 遠藤 広}

家鬼卵巣静脈血中の Progesterone と $\Delta^{4}$-Pregn-20 $\alpha$-ol-3-one とを化学的に定量すると, HCG 投与直後 てれら Progestin の分泌が増加する. 今回はIn Vitro で家鬼卵巣の Progestin 産生能について検索した. いづれの場合も組織は Slice にし, Buffer は Krebs Ringer phosphate Buffer pH 7.4, 0.1 Mole を用い,

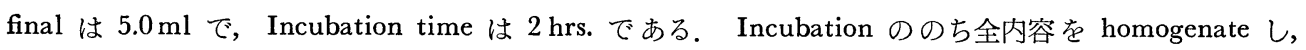
脱蛋白, ether 抽出後分配を行ない, amberlite IRC-50 を吸着剤とする Elution column chromatography で Progestin を分画し $240 \mathrm{~m} \mu$ の紫外部で定量した. 1. 非妊家鬼耳静脈から HCG 250 I.U. を投与し, 投与前に取り出した 1 側卵巣と投与後 10 分〜 2 時間後に取り出した 他側卵巣 とについて, IN VITRO で Incubation を行なつた場合では，(1) 投与前の卵巣は，いづれの場合（6回実験）もProgestin 生合成を認 めない．(2)投与後の卵巣は，投与時間の長短に関係なくおよそ $2.1 \mu \mathrm{g} / 100 \mathrm{mg}$ wet tissue の Progestin 生合 成を認めた. 2. 妊娠家鬼耳静脈から HCG 250 I.U. を投与し，投与前に取り出した 1 側沺巣と投与後 2 時間で取り出した他側卵巣とについて IN VITRO で Incubation を行なつた場合では, (1)投与前の間質 腺は $1.0 \mu \mathrm{g}$, 黄体は $0.5 \mu \mathrm{g}$, (2)投与後の間質腺は $10 \mu \mathrm{g}$, 黄体は $0 \mu \mathrm{g} の$ Progestin を生合成した。 3. 妊娠 家鬼卵巣を取り出し, (1) medium 飞 HCG $20 \mathrm{IU}$, を加光ない場合, 間質腺は, $2.5 \mu \mathrm{g}$, 黄体は $0.7 \mu \mathrm{g}$, (2) medium に HGG 20 I.U. を加えた場合，間質腺は，5.5 $\mu$ g, 黄体は， $1.8 \mu \mathrm{g} の$ Progestin 生合成を認めた。 以上より HCG を IN Vivo で投与した場合にみられる家鬼卵巣静脈血中の Progestin 増加の主たる因子 は，間質腺であると考えられる。

116. 6-dehydro-6-chloro-17 $\alpha$-acetoxy-progesterone の代謝

京府医大産婦人科 徳田 源市, 岡田 弘二, 石原 貞问, 阿原 道正 6-dehydro-6-chloro-17 $\alpha$-acetoxy progesterone ( $\left.4^{6} \mathrm{GAP}\right)$ は婦人科領域で広く使用されているが，今回は てれを tritium で lebel し，ウサギに投与してその尿中 metabolite について検討を行なつた，尿中に排泄 される radio-activity は他の各種黄体ホルモン郕に比して相当に長期間排泄されるのを認め，またその Distribution についても予想以上に free from の steroid が多くみられた。 抽出物を column chromatography によつて分画し, radio-activity の peak を大きく A, B , G の3 群に分けたが， A fraction は Girand 分画でほぼ全量が Ketonic fraction に，またB， Cは non-Ketouic 亿分画されるのを認めた。 さらに各 fraction を paper-chromatography で展開し，1 cm でとに切出してカウントのある部分につい て検討を行なつたが, 大部分の metabolite は $485 \mathrm{~m} \mu$ に $\mu \mathrm{V}$ 吸收の peak を示し, B, $\mathrm{C} の$ fraction は一部 $285 \mathrm{~m} \mu$ 亿eak を持つものもみられた. 以上の成績から A, B 環の還元の可能性も考えられるが, metabolite の多くのものは $\Delta^{6}$ GAP と同じく $\Delta^{4.6}$ diene-3-one 構造がそのまま残されているととを知つた.

117. $17 \alpha$-ethynyl-19-nortestosterone acetate および $17 \alpha$-ethynyl-4-estrene-3 $\beta$,

$17 \beta$-diol diacetate のウサギにおける代謝

京府医大産婦人科 德田 源市, 岡田 弘二, 村田 修吾, 折野 克彦

われわれは本学会において 17 $\alpha$-ethynyl-19-nortestosterone のウサギにおける代謝についてすでに報告し， また steroid ester の加水分解についても報告した。，今回は progestin acetate として $17 \alpha$-ethynyl-19nortestosterone acetate と $17 \alpha$-ethynyl-4-estrene-3 $\beta, 17 \beta$-diol diacetate をウサギに経口投与し，その尿中 metabolite について検討した. 水解抽出物は TLC にて展開し, trimethylsilyl ether 化後 GLC を行な つたとてろ metabolite と考えられる2つの保持時間の異なる peak を認めた。 その1つは標準品の $17 \alpha-$ ethynyl-5 $\beta$-19-norandrostane-17 $\beta$-ol-3-one に一致し, また TLC, paper chromatography での Rf も一致 した. 硫酸クロモーゲンスペクトルもその標準品とともに $310 \mathrm{~m} \mu$ に最高の吸収を示したのでての compound は $17 \alpha$-ethynyl-5 $\beta$-19-norandrostane-17 $\beta$-ol-3-one と考光られる。ほかのもう一つの compound は $\mathrm{CrO}_{3}$ 酸化により GLC で2つの peak を示し 1 つは標準品 $17 \alpha$-ethynyl-5 $\alpha$-19-norandrostane-17 $\beta$-ol-3-one に，ほかの1つはその G-5 の epimer の標準品に一致した。との両者を標準品を水素化ホウ素酸ナトリウ 
ムにより還元してえたものと比較検討した結果, $17 \alpha$-ethynyl-5 $\alpha$-19-norandrostane- $3 \beta, 17 \beta$-diol と $17 \alpha$ ethynyl-5 $\beta$-19-norandrostane-3 $\beta, 17 \beta$-diol と考えられる. 以上の点からとの両 progestin は acetate の水 解後 $17 \alpha$-ethynyl-19-nortestosterone と同じような代謝を経るものと考えられる.

118. $17 \alpha$-ethyl-4-estrene-17 $\beta$-ol および $17 \alpha$-allyl-4-estrene-17 $\beta$-ol の肝における代謝

京府医大産婦人科 岡田 弘二, 東 義隆, 西村 徹

合成黄体ホルモン剂である ethynyl-estrenol がヒトやウサギの体内で ethynyl-nortestosterone に変化す るととを前回報告したが，今回は 3-deoxosteroid である $17 \alpha$-ethyl-estrenol および $17 \alpha$-allyl-estrenol が ethynyl-estrenol の場合と同様 3-oxo steroid に変化するかどうかを，ウサギ肝の slice と incubate する ことにより実験検討したので報告する。 まず ethyl-estrenol をウサギ肝 slice と incubate し, 抽出して得 られた試料を ligroin-80\%-methanol 系 paper chromatography で展開すると, 紫外線吸収性の spot が 2 個得られた。 1 つは非常に極性の強いものでありその定性は行なわなかつたが，他の1つはあきらかに etyl-nortestosterone と同じ Rf 值を示し, gas chromatography でも ethyl-nortestosterone と同じ retention time を示した. さらに，また methanol 中での紫外線吸収スペクトルも 3-oxo-steroid に特徵的な $240 \mathrm{~m} \mu$ に吸収の peak を示した.つぎに allyl estrenol についての同様実験でも， gas chromatography， paper chromatography さらには紫外線吸収スペクトルにおいてもそれぞれ allyl-nortestosterone である ことが考えられた。

119. Estrogen の子宮組織核酸合成に及ぼす影響

阪大微研婦人科 垣田 守彦, 芝 茂樹, 森山 郁子, 須川 佶

Kirby の phenol 法により抽出したラット子宮の Estrogen dependent RNA を去勢子宮内に投与した ときの生物作用を報告して来たが，今回は Radio autography を用い Estrogen 投与時に RNA の新生 を mediator として DNA 合成が起ることを Actinomycin 投与によつて証明した. 又, Estrogen を投与 した際の，RNA 合成，DNA 合成及び RNA を直接投与した際の DNA 合成の時間的ずれについて検討 を加えた. RNA 合成に関しては, Estrogen 投与後 $3 \sim 6$ 時間で誘導され peak 亿達するが， DNA 合成 は，12時間目で開始し，24時間で peak に達する．又 RNA を直接投与した際の DNA 合成は，18時間で peak に達する. DNA 合成に関与する Thymidine kinase に対する Estrogen の影響についても観察した 結果，酵素活性の誘導が18時間目に最も高值を示す結果を得た. 以上の結果から，Estrogen が子宮に対し， 增殖肥大の変化をもたらすととは，RNA 合成に初まり，それが，細胞の分裂増殖に伴なう蛋白合成，でい ては RNA 合成し誘導するととを認めた。

120. Estrogen の作用機序 (第 3 報) In vivo に於ける子宮内膜 DNA 合成の regulation factor そ就いて

阪大微研臨床研究部婦人科 芝茂樹, 垣田 守彦, 田守 陳哉, 森山 郁子, 須川 佶

1. H³-thymidine を用いた Radioautography により, Estrogen 投与時に於けるラット子宮の endometrium の DNA 合成を観察すると, epitherial cell と stroma cell の反応性に多少の相違が存在すること を認めた。 2. puromycine 及び cyclohexamide を用い子宮組織の蛋白合成を阻害した際の endometrium の DNA 合成は去勢対照群にくらべ著明に増進されている． 3. 以上の結果は， $\mathrm{G}^{14}$-thymidine を用いた DNA 分画への incorporation を観察した際にも同様の成績であつた. 4. Progesterone 単独投与及び Estrogen との同時投与実験から Endometrium の DNA 合成に対し，Progesterone は抑制的に作用する という結論を得た. 5. 以上の結果より，Estrogen は cell division の G 1 stage から DNA synthetic stage へのうつりかわりを促進し, mitosis に導き endometrium に proliferation の像を呈するが, Progesterone は G 1 stage から DNA synthetic stage への junction であり Dichophase に作用し, differentiation の方向へもたらし, 結果として secretory endometrium の像を形成すると解釈される. また Dichophase そ於ける細胞の增殖と分化への分忮は, ある種の蛋白により regulate されている事を暗示せし める結果を得た。 
121. ラット子宮におけるグリコーゲン合成に及ぼす Estradiol の影響について（第二報）

奈良医大産婦人科 村上政, 岸田 秀雄, 徳井 宏, 高橋 義浩 estrogen が子宮の glycogen 合成を促進することは, 衆知の事実であるが，その機序については種々論議 されている. 今回私達は以下の実験を行なつた，1）去勢ラットに estradiol 投与, 8 時間後に ${ }^{14} \mathrm{C}-\mathrm{Glucose}$ を腸腔内投与, その子宮 Glycogen への incorporation が，去勢群に比し，著増し，しかも， ${ }^{14} \mathrm{C}$-glucose 及びその metabolite が子宮細胞内に多量に uptake されるととを知つた. 2 ) 子宮の glucose, glycogen content 血糖を測定， estradiol $(50 \mu \mathrm{g})$ 投与後 8 時間で，血糖值に変化がないにも拘らず，子宮 glucose， glycogen content の上昇を認め, ての glucose の上昇は chloride content と比較するととにより, intra cellular に accumulate されたものであるととを証明した. 3) Cycloheximide 投与，高血糖を惹起すれば， 去勢ラット子宮にも, その glucose, glycogen content ( $2 \sim 3$ 倍) となつた. estradiol 同時投与例では glycogen 合成に於いて Cycloheximide と相加作用は認められなかつた. 4) In vitro incubation に於い て, cold glucose を medium 亿加えると, その濃度に比例して去勢ラットにても, glycogen 合成が増加 した。その濃度が血糖值付近迄は, estradiol 投与子宮の方が, glycogen 合成が大であつた，以上の事実に より, 子宮 glycogen は, 子宮 glucose 濃度により, regulate されており, Estrogen は子宮膜透過性に影 響を及ぼし, glucose の transport を促進。その結果 glycogen 合成が促進される事を示唆する成績をえた。 122. 妊娠摘出ラット子宮筋の oxytocin 感受性に対する estradiol の影響

京府医大産婦人科 井上 正二, 杉原 養一

第40回日本内分泌学会総会において, 妊娠摘出ラット子宮筋の自動および oxytocin 収縮に及ぼす estradiol の in vitroにおける抑制作用について述べた。 そてで今回さらにそれを acetylcholine (ACh と略す) との関連性について検討し興味ある知見を得た。実験方法は Magnus 法を用い, 摘出ラット子宮筋の Oxytocin および ACh の感受性を比較検討した. 非妊ラットを estrus と diestrus に分けそれぞれの感受 性をみると, ACh 感受性は両者ほぼ一定であるのに対し, oxytocin 感受性は estrus が diestrus より高 い, このととは estrus における estrogen の増量か関係していると考えられ, さらに endogenous estrogen による ACh と receptor との結合阻害作用に起因していると考えられる. 次に妊娠後半期ラットに estradiol $0.1 \mathrm{mg}$ 筋注前および 4 時間後のそれぞれの感受性を比較してみると ACh に対する感受性は変化がな く oxytocin に対するそれは 4 時間後で明らかに上昇した。 ての機序も投与した estradiol の組織内 ACh 量の増加と ACh が receptor 亿結合するのを阻害する作用の両面より説明されうる. 次に非妊および妊娠 経過中の ACh に対する感受性は一定であるに反し, oxytocin に対するそれは妊娠時に高く, 妊娠経過と ともに上昇するのか認められた．とのととも上記の estrogen 作用とさらに progesterone の作用が加わつ て生じていると考えられる.

123. Progestin と Estrogen の下垂体 Gonadotropin 抑制効果

京府医大産婦人科 村上 旭, 東山 秀声, 小畑 義, 浜田 善弘, 小林 化也 木津 収二

合成 Progestin が臨床的に使用されているが，その1つとして少量の estrogen を添加して経口避妊の目 的に応用されている。 ての Progestin-estrogen 剂の作用機転として下垂体 Gonadotropin の分泌扣制が最 も大きな factor と考えられている. 今回, norethindrone と mestranol の20：1の比率からなる製剤につ いて下垂体 Gonadotropin への効果を検討した。，体重 $120 \mathrm{~g}$ 前後の Sprague-Douly 系の健常雌ラットにて の合剤を 1 日 $1 \mathrm{mg}$. 連続30日間投与した。 その結果卵巣重量は対照群と比較し著明に減少しており下垂体 Gonadotropin 分泌が強く抑制されることが推定された。 そてでての分泌抑制度をラットParabiosis を用 いて実験観察した，方法は Sprague-Douly 系のラットを使用し，体重 $80 \mathrm{~g}$ 前後の去勢雄と $90 \mathrm{~g}$ 前後の雌の Parabiosis を行ない手術当日より連続10日間去勢 Partner の背部皮下に steroid を注射し，注射終了の翌 日と殺, 各臟器の重量を計測した. norethindrone は total dosis $1 \mathrm{mg}$ では抑制効果はみられず10mg で認 められた. mestranol は total dosis $0.001 \mathrm{mg}$ ですでに抑制効果が認められ $0.1 \mathrm{mg}$ で強い抑制効果を示し 
た. 次にての合剤について実験したとてろ, total dosis $0.1 \mathrm{mg}$ で軽度の抑制効果があり total dosis $1 \mathrm{mg}$ では強い抑制効果を示した。これらのととは同時に卵巣組織像を観察してその卵胞の発育状況により確認さ れた．以上より norethindrone, mestranol の比率が20：1である合剤を皮下投与した時の gonadotropin 分泌の抑制は norethindrone によるよりは estrogen による方が優位であると考えられる.

124. 胎盤における Pregnane 系 Steroid の代謝について

名大産婦人科 石塚 直隆, 千原 勤, 戸谷 良造, 鈴木 正英, 岡田 和嘉
熱田 明, 太田 正博, 蜷川 映己

胎盤性 pregesterone 产出が de novo synthesis とよるものか，血中 pregnenolone の利用にあるのか， また HCG がどのように関与しているかを研究するため, 次の実験をおてなつた。1. 胎般灌流実験によ り, cholesterol から progesterone への conversionは0.07\%, pregnenolone から progesterone は $3 \%$ であつた. 2. Wistar 系 rat そ HGG を投与し, 副腎 $3 \beta$-ol-steroid-dehydrogenase の活性の低下をみとめ た。以上の結果は，血中 pregnenolone を利用して胎盤性 progesterone 産生を行なつているてとが推測さ れるが，同じ HCG 支配下にある䋐腫患者では，尿中 pregnanediol 排泄量が少ない，ての点を解決する ため 1. Mole 組織と正常絨毛の aryl-sulfatase, steroid sulfatase, $3 \beta$-ol-steroid-dehydrogenase の活性を 測定したが，両者に差を認めなかつた．2. Cell の構筑や anatomical な差による点を検討するため， 3 comparment model を組立て in vivo $飞$ pregnenolone- ${ }^{-3} \mathrm{H}$ および progesterone- ${ }^{-14} \mathrm{C}$ を同時に静注し，尿 中 pregnanediol の specific activity より次の值を得た. (A) progesterone の production rate は妊娠 例では, $151 \mathrm{mg} / \mathrm{day}, 73 \mathrm{mg} / \mathrm{day}$ であり 緁䭪例では $4.6 \mathrm{mg} / \mathrm{day}, 22 \mathrm{mg} / \mathrm{day}$ と大きな相異を認めた. (B) pregnenolone から progesterone への conversion factor は，妊娠例ではより高率に血中 pregnenolone を progesterone に convert している.

質問：神大産婦人科 東条 伸平 この種の steroidogenesis 飞関与する母体副腎と胎児副腎の何れに より大きな意義があると怙考えか.

応答：名大産婦人科 戸谷 良造 1 . fetal adrenal の $3 \beta$-ol dehydrogenase を測定しているかの問 飞対し. 我々は成熟メス rat に HCG を投与し, その副腎 $3 \beta$-ol-steroid-dehydrogenase 活性の低下より, 妊娠時, 母体副腎の $3 \beta$-ol-dehydrogenase activity あ低下している可能性があると考えている，2，胎児副 腎加らの Pregnenolone の意義について。胎盤性 progesterone が de novo synthesis によるものか, 血中 pregnenolone を利用しているのか，未解決であり，胎児副腎からの pregnenolone-sulfate の役割りにつ いては解らないが, 我々の Compartment model より, 尿中 $\Delta^{5}$ pregnenediol を測定すれば, pregnenolone の secretion rate も計算できるので胎児副腎の関与の有無にもかなり解決ができるものと思う。

応 答: 名大婦人科 蛈川 映己 Fetal part 加らの pregnenoloneないしその sulfate か, moternal か という問題の前に私達は, まず, de novo synthesis が main role を演ずるのか, pregnenolone sulfate から の conversion なのかを解明すべきだと考えた。今回は発表しなかつたが，現在実験中の結果からは， pregnenolone の産生量は, 奸娠時 progesterone 産生を説明するには充分でなく, de novo synthesis が main role を果しているとの impression を受けている. 胎児側の pregnenolone の寄与に関しては, 胎 児側 compartment に radioactive steroid を入れることの困難さから今後の追究にまちたいと考元ている. 125. 男子における尿中 Estrogen の定量 —R.I., Ittrich fluorometry一

岡山大泌尿器科 大北 健冕, 田中 啓幹, 高田 元敬, 斉藤 利興 先に神戸川が報告した尿中 estrogen の Isotope dilution method を modify し測定した. 3 step hydrolysis による7 例平均の各収量は $\beta$-G $54.5 \%$, solvolysis 30.3\%, hot acid $15.5 \%$ であつた. 超音波による methylation の収量はスターラーより10\%〜20\%の好収量を得た. Packard の Liquid scintilation counter 亿よる $\mathrm{E}_{1}, \mathrm{E}_{2}$ の cpm と濃度の関係は $\mathrm{E}_{1} 27 \sim 80348 \mathrm{cpm}, \mathrm{E}_{2} 32 \sim 91263 \mathrm{cpm}$ で，測定範囲内直線で あつた. Farrand の Spectrofluorometer による fluororescence intensity と $\mathrm{E}_{1}, \mathrm{E}_{2}, \mathrm{E}_{3}$-methylether の濃 度との関係は夫々 $4 \times 10^{-3} \sim 2.0 \mu \mathrm{g} / \mathrm{ml}, 4 \times 10^{-3} \sim 1.0 \mu \mathrm{g} / \mathrm{ml}, 2 \times 10^{-3} \sim 4 \times 10^{-1} \mu \mathrm{g} / \mathrm{ml}$ で直線となつた. 尚, 
励起波長 $535 \mathrm{~m} \mu$, 螢光波長 $550 \mathrm{~m} \mu$ で測定した。 実測範囲（低濃度）では scatter のため Allen の補正は 不可能であつた。 Tritium を用いて step recovery を行なつたが, total では $\mathrm{E}_{1} 25.0$ 18.2\%， $\mathrm{E}_{2} 23.6$ $17.6 \%$ であつた． 6〜 72才までの正常男子12例（幼年，壮年，老年各 4 例）に於いて，我々の測定方法の 值と神戸川 年 $\mathrm{E}_{1} 0.33 \sim 4.79, \mathrm{E}_{2}$ 0.25 2.23, 壮年 $\mathrm{E}_{1}$ 6.39 12.05, $\mathrm{E}_{2}$ 3.27 3.94, 老年 $\mathrm{E}_{1} 4.42 \sim 8.63 ， \mathrm{E}_{2} 2.01 \sim 6.41$ $\mu \mathrm{g} / \mathrm{day}$ で, この值は他の 2 方法に比較して range が小さく安定した值を示した.

126. 肝疾患時における尿中 estrogen 排泄值について（第 2 報）

岡大小阪内科 $\bigcirc$ 福島 功, 有正 修過

肝疾患時にしばしばみられる Vascular Spider (V-S) Palmar Erythema (P-E) Gynecomastia (Gyn)の ある症例について尿中排泄 Estrogen 量を定量した。測定法は尿 $200 \mathrm{ml}$ 用いて 1st step $\beta$-Glucuronidase 水解 2nd step solvolysis を行ない Ether 抽出後神戸川E法に準じて Estrone $\left(\mathrm{E}_{1}\right)$ Estradiol $\left(\mathrm{E}_{2}\right)$ Estriol $\left(\mathrm{E}_{3}\right)$ の 3 分画をとり Salokangus の micro-method を modify して比色定量を行なつた．対象はすべて男 子を選び正常 V-S, P-E, V-S + P-E, P-E+Gyn, V-S + P-E+Gyn の各群それぞれ 13，2，4，11，2，5 例について検討した. $\mathrm{E}_{1}, \mathrm{E}_{2}, \mathrm{E}_{3}$ Total estrogen の正常例の平均は $1.55,1.60,3.81 \mu \mathrm{g} / \mathrm{day}$ であり各症例 群ともバラッキが多く $0.27 \sim 8.97 \mu \mathrm{a} / \mathrm{day}$ であつた. $\mathrm{E}_{3} /\left(\mathrm{E}_{1}+\mathrm{E}_{2}\right)$ は正常例の平均は 0.933 であつたが各症例 群とも低值を示し特に V-S+P-E+Gyn. のある群では平均0.418で最低であつた. 即ち $16 \alpha$-hydroxylation の障害のため $\mathrm{E}_{3}$ への代謝が抑制された結果であり，てれらの症状と何らかの関係があると推定された．次 飞 Estrogen conjugate $\beta$-Glucuronidase 水解で Glucuronide fraction $(G)$ を Solvolysis で Sulfate fraction (S) に分けて測定した。対象は正常 5 例，肝硬変11例で， $E_{1}$ では $G, S$ 共に正常に比しやや高く $\mathrm{E}_{2}, \mathrm{E}_{3}$ では $\mathrm{G}$ で肝硬変症例に低く $\mathrm{S}$ で高い順向があつた。 $\mathrm{G} / \mathrm{S}$ はすべての fraction において肝硬変症に低 値を示した。

追加：質問：九大産婦人科周村靖 2 step Hydrolysis と Brown 法とで尿中 strogen 分画值にどの ような差がみられるか. Helix pomatia に上る醳素水解（sulfatase と $\beta$-Glucuronidase とを含む）之 Brown 法とを比較してみると estradiol の破壊が認められる。

応答：岡山大小坂内科福島 功 (1) Bron の方法の hot acid hydrolysis の方が 2 step hydrolysis より低値となつた。(2)対象は男子例のみ. (3)正常值は年令20〜30台のものをとり，肝疾患群で最高 50 万 台まであり，年令的な推移は検討を行なつていないので今後やつてみる必要があると思う.

127. ラット卵巣の estrogen 分泌の周期的変動

塩野義研究所 ○堀 喬, 井手 誠, 加藤 五郎, 三宅 有

既に我々の設定した血中微量 estrogen 定量法（日本内分泌誌，42：1350，(1967)。第14回日本内分泌学 会西日本地方会）を用いてラットの性周期に伴なう卵巣静脈血中の free estrogen 值（以下 $\mathrm{E}$ 值）の推移を 測定し次の結果を得た。卵巣静脈血中E 值は diestrus 1 日から diestrus 2 日目の午前まで低值 $(0.2 \mathrm{ng} / \mathrm{ml}$ plasma）を示すが什後より顕著な増加が始まり翌日の proestrus の午前11時に極大值 $(4.5 \mathrm{mg} / \mathrm{ml}$ plasma) に達する。 とてろが排卵にはるかに先行して下垂体から LH の放出の始まる時期（演題17番参照）から $\mathrm{E}$ 分泌は急減し始め, proestrus の午後遅くには成熟卵胞が存在するにもかかわらず $\mathrm{E}$ 分泌は殆んど停止する. Proestrus のE 分泌元進期に脳下垂体を剔除するとただちにE分泌は急減し, 術後 3 時間以内に diestrus の level にまで低下するが麻醉処置のみでは著変がない，更にての様な条件の脳下垂体剔除ラットに NIH-LH， NIH-FSH を静注すると30分以内に E 分泌は再び充進し，その作用は 3 時間以上持続する。 ての様な $\mathrm{E}$ 分泌 促進作用は FSH の方が強く, ての群の $\mathrm{E}$ 分泌は正常群を上まわる. 以上の成績は proestrus 期における $\mathrm{E}$ 分泌，換言すれば成熟卵胞を有する卵巣の $\mathrm{E}$ 分泌か脳下垂体性因子に直接支配されている事を示すものであ り，その分泌促進因子はL L よりもむしろ FSH である可能性が強い．従つて E 分泌の交進が L H 放出に 先行する事実と併せ考えると，ラットではLHとE分泌の間に positive feedback の関係が存在するとは考 光難い。 
質問：神大産婦人科 東条 伸平 扮用いになられた FSH の LH contamination の程度は如何か. estrogen の産生には FSH と GH のある種の ratioによる同時作用が必要なのではないだろうか. 応答：塩野義研 堀 喬 用いたのは NIH の FSH で少量の LH は含まれているが $\mathrm{E}$ 分泌促進 作用は contami している LH の作用でないと考えている。成熟卵胞存在下の卵巣の $\mathrm{E}$ 分泌に拈ける FSH LH の協調作用の有無は検討中である.

128. ラット卵采の progesterone 及び 20 $\alpha$-hydroxypregn-4-en-3-one 分泌の周期的変動 塩野義研究所 内田 清久, ○門脇 真澄, 宮田 研司, 三宅 有

私共は Thin-layer chromatography と gaschromatography との組合せによる卵巣静脈血中 pregn-4-en3,20-dione (20-oxo) 及び 20 $\alpha$-hydroxypregn-4-en-3-one (20 $\alpha$-OH) の同時定量法を確立し, smear test で 4 日の正常周期を示す成熟雌ラット (Wistar 系) の卵巣から分泌される両ステロイド量 ( $\mu \mathrm{g} / \mathrm{hr} / \mathrm{ovary})$ の 推移を検討し，次の結果を得た。 20-oxo の分泌は early diestrus $\left(\mathrm{D}_{1}\right)$ 19時に軽度の上昇(最低時の約 7 倍) を示した後ゆるやかに下降，翌 late diestrus $\left(\mathrm{D}_{2}\right)$ の19時より翌日 proestrus $(\mathrm{P})$ 17時まで最低值 $(0.22 \pm$ 0.02）を示し，その後急上昇して 19 時より 23 時まで最高值（3.31 $00.35 ）$ を示した後下降し，次の日の estrus (E) 10時より19時に至つて低值をとり，次の $\mathrm{D}_{1}$ におけるゆるやかな上昇に連なる。すすなお， $\mathrm{D}_{1}$ 午後から $\mathrm{D}_{2}$ 午前にかけての低くゆるやかな山と $\mathrm{P}$ 午後から $\mathrm{E}$ 午前にかけての急唆なピークを示す. $20 \alpha-$

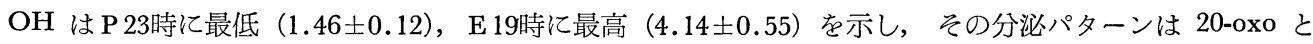
一致しない. なお，17時より19時にかけての 20-oxo の急上昇は下垂体のL H放出時刻に一致する（演題17 番参照). 従つて, 排卵前における卵巣 20-oxo 分泌の一過性无進は下垂体の L H 放出と密接に関連してい るが，20 $\alpha-\mathrm{OH}$ 分泌の変動は血中 L H值と密接に関係していないので 20-oxo 分泌とは異なつた機序によつ て調節されているものと考える.

追 加：京大第 2 解剖 清水 勘治 (1)ラットのプロエステラス期に拈ける卵巣からのプロジェステロン 放出量があなたの実験では maximum になつているが私の場合は minimum である。私の実験ではプロジ エステロン放出量の最高值はジェストラス期に現われる。との点抢そらくあなたのプロエステラスの選定法 は私のジェストラス期に相当すると思われるが如何か. 更にプロエステラス期では Corpus luteum は活動 していないてとからあ，プロジェステロン放出量が maximum になるのは掞かしい. (2) LTH と卵巣から のProgesterone 産生分泌之の間に相関関係はあると考えられるか.

応答：シオノギ研究所 門脇 真澄 Progesterone の分泌は12時間照明の条件下では proestrus の午後 7 時に最高值を示すが血中LH濃度の peak と一致する事からLHの作用によると考える，LTHについては 検討していないが質問の如く, diestrus 期に分泌されるのであれば early diestrus 期に認められた progesterone の peak が LTH の作用によるむのかむ知れない.

129. Nidation の機序に関する実験的研究 第 2 報

一特にestrogenの着床阻止並びに促進作用について一

神大産婦人科 林 要, 高野 申五, 岡村 博行, 近藤 千里, 谷 立夫 光辻 烈馬, 東条 伸平

$\mathrm{L}_{0}$ の妊娠ラットに EE-3ME を投与すると投与量を増すに従い $\mathrm{L}_{1}$ における卵回収数は減少し，一部の 卵は子宮腔より回収されると共に着床数は 0 となつた. estradiol 投与時にも同様の傾向を示した. estrogen 投与前に 1 側の子宮角基部え結紮すると結禁側子宮より正常妊娠と同数の卵を回収し得た. 以上の成績から $\mathrm{L}_{0}$ に estrogen を投与した際の着床阻止機序は卵管の卵輪送速度が加速され子宮が着床準備状態となる前に 未熟な卵が子宮腔に到達し，更に子宮の運動性も昂進して早期に卵が子宮腔より排出される事がその原因の 1つである. 着床促進作用については delayed implantation ラットに estradiol を投与して着床状態を検 討した。実験方法は $\mathrm{L}_{2}$ に卵巣を摘除し, 以後 progesterone を $4 \mathrm{Iug}, 2 \mathrm{mg}$ 単独投与し， $\mathrm{L}_{10}$ に着床の有 無を確めた後に estradiol $0.2 \mu \mathrm{g}, 0.1 \mu \mathrm{g}$ を連続或いは 1 回併行投与した. $\mathrm{L}_{17}$ の着床数はどの Group も 5 ケ平均であつたが, estrogen sensitiation 後の日数が同じである正常妊娠子宮と比較すると着床数, 発育が 
劣つて居り, 配列の乱れ, 大小不同がみられた， $\mathrm{L}_{4}$ 亿去勢し以後 progesterone 単独投与ラットでは着床数 は正常妊娠ラットと差がなかつた. 又, delayed implantative 中の blastcyst $\left(\mathrm{L}_{10}\right)$ の大きさは control と 較べて 20〜30 $\mu$ 大となつており, 又, blastcyst cavity の拡大, trophoblast cell の扁平化, inner cell mass の縮少の如き形態的変化が認められた。 尚 Zona pellucida は全く認めなかつた. 以上の事からラット受精 卵着床に estrogen が必要である事が判明した。

130. 月経異常及び無排卵と脳波との関連について

九大産婦人科 岡村 靖, 後藤 哲也

最近九大婦人科を受診した月経異常患者 49 例, 即ち原発性無月経 6 例, 続発性無月経 28 例, 無排卵周期 13 例, 排卵性稀発月経 2 例につき脳波の記録を行ない, 全例に安静覚醒時, 過呼吸及び閃光刺激珷活を行ない, 36例に塩酸 Diphenhydramine 静注法による睡眠賦活を行なつた結果，27例（55\%）に軽度或は中等度の 徐波化, 沉発性の slow burst $6 \& 14 \mathrm{cps}$ positive spike 等の異常が認められ, 下田等が間脳を含む脳幹の 異常を示す波型として取り上げた汎発性 slow burst と $6 \& 14 \mathrm{cps}$ positive spikeの両者を合せた出現頻 度は49例中14例 $(28.6 \%), 6 \& 14 \mathrm{cps}$ positive spike のみの出現頻は49例中 8 例 $(16.3 \%)$ であつた. 又 上記月経異常別にみると, 原発性無月経や続発性無月経II度において異常脳波の出現率が高かつた。更にて れ等の月経異常について, rapid AGTH test 及び Vasopressin test を行なつた結果, いづれに於ても脳波 異常群と正常群との間に著明な差は認められなかつた。

質問：岡大神経精神科高坂睦年 月経異常或は無排卵之脳波の関係は大変興味があるが, 所謂間脳 症の背景之考えられる他の身体的或は精神的な症状の検索については如何であるか.

応答: 九大婦人科 後藤 哲也 無月経以外の明らかな身体症状を呈する者は症例加除いている。テ ンカンは含んでいない，又心理的な面については知能テスト及び心理テストで検索を進めている。症例を重 ねて EEG との相関について報告する予定である.

131. イソ染色体Xを伴なつた Turner 症候群の一例

大阪市大和田内科 西山 惠夫, 谷口 徹, 木下 迪男, 和田 正久 患者は23才の女性で発育不全, 無月経を主訴として来院. 家族歴では特記すべきてとなく, 既往歴では 4 年前から頭痛時に常用している鎮痛剤による薬掺が出没する他には特記すべきてとはない．現病歴では 5 才 位から身長の伸びが遅延し，現在に到る．未だに初経を見ない．入院時所見では身長 $131.3 \mathrm{~cm}$, 体重 $41 \mathrm{~kg}$, 胸囲 $77 \mathrm{~cm}$, 坐高 $75 \mathrm{~cm}$, 頭囲 $52.3 \mathrm{~cm}$, 指極 $126 \mathrm{~cm}$ で短軀. 腋毛恥毛は少なく乳房の発達やや悪く鎧状脍で 外反时は見られるが，翼状頸は見られない，検査成績では軽度の正色素性貧血はあるが出血傾向はない，血 清梅毒反応は陰性。電解質は血中及び尿中共異常なく糖負荷試験で血糖値は正常であるが腎性糖尿がみられ る.レントゲン検査では骨年令は17才程度でトルコ鞍はほぼ正常大で骨破壊像はない. 腎孟撮影で馬蹄腎が みられる。婦人科的には子宮及び臸の発育不全があり外陰部の発達は良好. 基礎体温曲線は二相性を示さず. 鈴木ビネー式知能検査では 12 才 8 ケ月位. 脳波には異常なし. 肝機能検查, 甲状腺機能検查, 副腎機能検査 には異常はないが尿中ゴナドトロピンは32単位以上の高値を示す。染色体検查では性染色質は陽性で大型で あり, 染色体数は46個で性染色体は X iso X の構成を持ち, ターナ一症候群であることか判明した.

追加, 質問: 高知県立中央病院産婦人科本森良治 X染色体の Short Arm 欠損 Type X の Turner Syndrom の一例を本学会に発表したが，XO 型に比しクリトリスの肥大を認めたが御発表の例ではいかが であつたか。

応答: 大阪市大和田内科谷口 徽 正確な計測は行なつていないかむしれないが, 本例を診察した 婦人科医の報告では外陰部は正常とされている.

132. $\mathrm{XX} / \mathrm{XXY}$ Klinefelter 症候群

京大泌尿器科 酒德治三郎, 吉田 修, 高山 秀則, 岡田謙一郎, 小松 洋輔 症例は 33 才の外観上男子で, 約 7 年間の不妊を主訴として来院した, 身長 $172 \mathrm{~cm}$, 指極間 $184 \mathrm{~cm}$, 女性化 乳房, 倭小睪丸を認めた。尿中ゴナドトロピン排泄值 48単位以上/day, 尿中 $17 \mathrm{KS} 6.1 \sim 7.85 \mathrm{mg} / \mathrm{day}$, 尿 
中 Estrogen $8.0 \mu \mathrm{g} / \mathrm{day}$, sexchromatin 陽性, 性染色体構成 XX/XXY
質 問：関大泌尿器科 田中 啓幹 出生時の両親の年令は.
応答: 京大泌尿科 小松洋輔 父母の年令は共に20才の第 1 子で, 同胞 1 名（男子）である.
質問：岡大神経精神科 高坂 睦年 私共以前 XXY 型の Klinefelter一例を見たが，乙の症例は周 期的に女性的な behavior を呈した。先生の症例で何か精神症状で面白い所見があつたら沶示し願いたい. 応答：京大泌尿器科 小松 洋輔 ロールシャッハテストで男性としての性格は形成されている.

133. HCG 投与後の家鬼卵巣に於ける脂質動員に関する考察

$$
\begin{gathered}
\text { 阪大第 } 2 \text { 病理 岡野 錦弥, 永井 清和, 松本 圭史, 虎頭 廉, ○花井 淳 } \\
\text { 田中 要 }
\end{gathered}
$$

HCG 投与後の非妊家鬼畉巣の動態を知る目的で以下の実験を行なつた。成熟非妊家鬼を 8 匹用い, HCG 100 I.U. 投与後 2 時間， 8 時間，48時間，72時間にそれぞれ 2 匹ずつに分けて実験した。 nembutal 麻酔後 左側卵巣静脈血を採取して直ちに，その側の卵巣を剔出し control とする. 結禁後 HCG 100 I.U. 投与し て経時的に右側の静脈血と卵巣を採取し，それぞれの分画について各脂質の定量を行なつた。 又同時に卵巣 静脈血漿の lipoprotein lipase 活性を測定し, 前回報告した組織での活性と比較した. 測定の結果は, 組織 では $\mathrm{mg} / \mathrm{g}$ W.W. で, 又血漿では $\mathrm{mg} / \mathrm{dl}$ で単位を統一し, それぞれ control と比較して増減を調べた。 脂質定量については, total lipids は Searcy 変法, total cholesterol は Zac Henrry 変法, Phospholipids は Fiske, Sabarrow 法, 又 NEFA は Ui, Itaya の方法を用いた。 total lipids は組織では著しい増減な く, Plasma では48時間以後で増加して若干 lipemic となつた. NEFA は血漿で減少した。特に著しい変 化は, total cholesterol 及び phospholipids であり, 時間的経過により特異的変化を示した. 即ち cholesterol は卵巣組織に於いて減少した。 ての場合, 卵巣が含有する絶対量で比較すると48時間以後で増加する. phospholipids は組織において経時的に漸増した，以上の如くHGG により卵巣脂質は動的となる。血漿 リパーゼ活性（pH=8.5）は HCG 投与後48時間で活性の低下を示し，組織りパーゼと逆になつた。

134. HCG 投与後の非妊家鬼卵巣の Lecithinase 活性の検討

阪大第 2 病理 岡野 錦弥, 永井 清和, ○花井 淳, 和田 武郎, 田中 要 我々が既に報告した燐脂酸の変化が, HCG の及ぼす重要な変化であれば, HCG 作用後畉巣 Lecithinase (この場合特に Phospholipase B) 活性上昇が一つの問題と考えられた. そてでおおよその Lecithinase 活 性を測定すべく以下の測定法を考按して検討した. Incubation medium は, 86.7\% Lecithin を含む crude な Lecithin 製剤を substrate とし，検定すべき組織の $0.1 \mathrm{M}$ glycine- $\mathrm{NaOH}(\mathrm{pH}=8.9)$ とよる homogenate を用い, 種々の酸素賦活剤を加えて 2 時間 incubate する. Lecithin より遊離した脂肪酸を colorimetric 飞測定し, 脂肪酸の産生をもつて活性の強さとした. Phospholipase B は, ラット肝に存在し, そ の組織 homogenate を用いて, Optimum な条件を決定した. 即ち醳素賦活㓮の量を決定し, pH では $\mathrm{pH}$ $=8.9$ が Optimum である事, 又 time course は 2 時間で頂点に達する事を得た。 又酵素濃度直線は $1 \%$ Pancreatic lipase を用いると比例直線を得たので, 本法は活性の大略を知るのに有効である事がわかつた。 家鬼肝ではラット肝のほほ $1 / 3$ の活性を示し, 低值であるが存在が認められた. 次に 1 群 4 匹の非妊家鬼を 用い, 麻醉後 1 側卵巣を剔除して Control とし, HCG 100 I.U. 耳静脈注射後 2 時間にて他側卵巣を採取 し，その 4 匹の卵巣をそれぞれ合せて，Lecithinase 活性を比較した。乙の実験は 2 回行なつたが，我々の 方法では, Control も HCG 投与側も detect 出来ず, 従つて phospholipase B が HCG の第一次の作用 点とは云えない結果に終つた。

135. 尿中テストステロンについて

岡大産婦人科 吉田 俊彦，○国富慎一郎

先に我々か溌表したテストステロン測定法により排卵性女性周期, 男性, 諸種疾患について尿中テスト ステロンを測定し, 更に各種薬物負荷試験を行ない, その結果について報告する. 排卵性女性の尿中テス トステロン及びェストロゼンの周期変動に伴なう推移はよく似ており, 増殖期, 中期及び排卵期に稍々おく 
れて二峯性を示した。 クッシング症候群では尿中テストステロン排泄值が高かつた，女性の多毛症では女性 と男性の中間值を示すものが多かつた。 3 例の膠原病では甚しく高值を示した。副腎, 性腺の抑制, 刺激試 験を行なうと, 内分泌腺の動的機能を明確に出来ると考学られた。無排卵患者におけるダイナミックテスト の結果により, 卵巣性テストステロンの存在は明らかであり, 且つ, エストラジオールの分泌量と解離する 例があるととは, 卵巣における代謝傾向の相異によるものと考朰れ興味深い. 尿中テストステロンは, 卵 巣性, 副腎性いづれも存在し, よいアンドロゼニンティーの指標として, 臨床上, その判定は有意義なもの と考えられ，更に他のエストロゼン分画，アンドロゼン分画と同時に測定するととにより代謝の傾向がうか がうととが出来る重要なステロイドと考えられる.

136. $\mathrm{H}^{3}$-Dehydroepiandrosterone sulfate を用いた人血漿中の Androgens の分泌 と代謝に関する臨床的究

$$
\begin{aligned}
\text { 京大深瀬内科 深瀬 政市, 河野 剛, 山田 重樹, 辰己 学, 大迫 文麿 } \\
\text { 平盛 勝彦 }
\end{aligned}
$$

正常人について, 血漿 Dehydroepiandrosterone sulfate (DHA-S) の血漿中濃度. metabolic Clearance Rate 及び Blood production rate を Conrad 等の方法 (J. Clin. Invest. Vol. 40. 947. 1961) 及び Tait 等の理論 (J. Clin. Invest. Vol. 40. 72. 1961) 飞従つて測定し算出した。血漿中濃度は, 血漿 $15 \mathrm{cc}$ に 回収率補正の為既知量の $\mathrm{H}^{3}$ 標識 Dehydroepiandrosterone sulfate を加光, 除蛋白後 Florisil Column 及び paper chromatography にて DHA-S を単離純化し，それを二分し，一方はその放射能を測定し，一 方は Microzimmermann 法により定量し，回収率補正後血漿 DHA-S の濃度を算出した. Metabolic clearance Rate (MCR) は. Tait 等の two compartment model によつて, 算出し, Blood Production Rate は. MCR と，血槳中濃度の積により算出した。そ結果，正常人男子 5 例では，血漿中濃度は 145 , $260 ， 224 ， 196 ， 206$ 各 $\mu \mathrm{g} / 100 \mathrm{ml}$ を得, 平均 $206 \pm 37.6$ (S.D.) となり, 正常人女子 3 例では，258，211， 296 各 $\mu \mathrm{g} / 100 \mathrm{ml}$ を得, 平均 $254 \pm 34.0$ (S.D.) $\mu \mathrm{g} / 100 \mathrm{ml}$ となりました. 男女間には, $1 \%$ の危険率をもつ て有意の差があるが，症例少なき為に断定したととは云えない．MGR は 1.12, 1.95, 1.99 1/day, 平均 1.69 $\pm 0.40 \mathrm{l} /$ day であつた. Blood production rate は 2,91, 4.03, 3.91各 $\mathrm{mg} /$ day 平均 $3.62 \pm 0.86 \mathrm{mg} / \mathrm{day}$ であつた. 教室で先に測定した Urinary production rate とほぼ一致した值を得た.

137. Leydig cell hyperplasia の電子顕微鏡的観察

京大泌尿器科 加藤 篤二, 酒徳治三郎, $\bigcirc$ 高山 秀則, 小松 洋輔 男性不妊患者に対して殬丸生検を行ない，光学顕微鏡的に Leydig cell hyperplasia 2 例に対して Leydig 細胞を中心に電子顕微鏡的観察を行なつた。 Leydig 細胞は互いに相接して群集を成しているが, 細胞間の結合は疎で，軽度の嵌合を認める程度である．又所々に細胞間隙を認め，ててでは細胞質に偽足様 或は絨毛様の突出を認める。細胞質には vesicular の滑面小胞体が著しく発達しており，粗面小胞体はわず かに散見されるに過ぎない，糸粒体はよく発達しており，2３個の crista か滵着する傾向にあり，隣接 する crista 間で loop を形成しているもの, lamella を成しているもの, 篧状のもの等, 特徴ある所見を 認めた。 又, 糸粒体基質には mitochondrial granule の他に， lipid と思われる顆粒が存在した．細胞質に は lipid 顆粒が正常のものより減少しており，3〜6本の microfilament 上り成子糸状構造物が著增して いるのを認めた。 2 本の平行した膜があたかも玉ねぎの様にうずを巻いて形成されている所謂 whorl は認 められたが, Reinke の crystaloid は2 例共に見出せなかつた. 結局光学顕微鏡的には hyperplasia を呈 していたが, 電子顕微鏡的に細胞内小器官は機能的に低下していると思われる所見を認め, 臨床的に androgen 過㮃の症状及び所見を認めないととを考え併せ，個々の細胞は androgen 分泌が減少しているものと 推察される.

138. マウス悬丸 DNA 代謝に対する各種金属塩の影響

広島大泌尿科 松本 暁, 仁平 宽己, 石部 知行 マウス睪丸精細胞の DNA 合成を観察する目的で, 生後 4 週間 $10 \mathrm{gr}$ 前後の D.D. 系マウスに $\mathrm{H}^{3}$-thym- 
idine を経腹膜的に投与し，投与後経時的に屠殺してオートラジオグラフを作成，H.E. 染色標本と比較観 察した. マウスは $\mathrm{CdCl}_{2} 5 \gamma / \mathrm{gr}$ B.W., $\mathrm{PbCl}_{2} 20 \gamma / \mathrm{gr}$ B.W., $\mathrm{CuSO}_{4} 20 \gamma / \mathrm{gr}$ B.W. を各々経腹膜的に投与した ものとそれらの対照群即ち 4 群を更に投与後 24 時間（A群）と投与後 7 日（B群）の 2 群にわけた計 8 群に 対して上記方法にて処置した。我々の場合, $\mathrm{CuSO}_{4}$ 投与群では $\mathrm{A}, \mathrm{B}$ 群ともに H.E. 染色標本でもオート ラジオグラフにおいても対照群とほとんど差がなかつた. $\mathrm{PbCl}_{2}$ 投与群でも H.E. 染色標本及び比体重のう えでほとんど対照と差はなかつたがオートラジオグラフでは取り込みの軽度な減少が認められた．H.E. 染 色標本上，また比体重において対照と明らかな差を認めた $\mathrm{CdCl}_{2}$ 投与群ではオートラジオグラフで著明な 取りこみの減少を認めた。

質問：京大泌尿器科 加藤 篤二 Isotopeで睪丸障碍を起して検索する場合の技術的注意は何であるか.

応答: 広島大泌尿器科松木喷 1 . 使用するアイントープの半減期が問題であり,バックグラウン ドに影響しないあのを用いねばならない，2．すでに Cd と Zn の拮抗作用についての報告を知り，今後 検討していきたい.

139. 乳癌の薬物的内分泌療法に関する検討

愛知県がんセンター外科第 2 部 竹内 新治, 吉田楥 愛知県がんセンターに於いて, 開院以来 2 年半の間に, 薬物的内分泌療法を施行した進行乳癌症例は60例 で, その内訳は Androgen 投与41例, Estrogen 投与19例である. 比等の症例に就いてその効果を検討し, 又てれを外科的内分泌療法を施行した症例と比較して次の結論を得た。尚, 効果を明確に知る為に症例は, すべて転移が広範囲に亘り, 切除又は放射線療法の対象となり得ない上, 症状の進行が明らかなもののみを 選び，1 ケ月以上他覚的にすべての転移巣か㳊善された場合を有効とした。結論：1）Androgen の有効率 は閉経前症例で17\%，閉経後症例で27\%，平均 $25 \%$ あつた。. 薬剤別では Halotestin の有効率が高く, 且 つ投与か容易なので臨床的に最も優れている，2）一方, Estrogen はすべて閉経後の症例（閉経後平均 11.4 年）に用いられたが，明白な有効例は 1 例も得られなかつた。 3) Androgen の有効率は，対象として行な つた制癌剂療法の有効率 $8 \%$ より遙かに優れているが，外科的内分泌療法の有効率（1 ケ月以上 $53 \% ， 6$ ケ 月以上 $38 \%$ ）飞比べると，かなり劣る．4）Androgen 投与が有效であつた症例の, 平均有効期間は，3.1ケ 月で, 外科的内分泌療法の平均 9.1 ケ月に比し，短期間で再燃を来たす．5）転移の種類別に有効率を検討 すると, Androgen 投与の臟器転移に対する効果は悲観的である.

140. 含硫新ステロイド 10275-S の Shionogi carcinoma 115 に対する作用 塩野義研究所 峰下 銕雄, 山口 健二

既報の如くShionogi carcinoma 115 は男性ホルモン依存性腫愓である. この性格を利用して制癌剤スク リーニングの実験中, 当研究所の武田, 米野らによつて合成された 10275-S $(2 \alpha, 3 \alpha$-Epithio- $5 \alpha$-androstan$17 \beta$-ol）が著明な腫愓増殖作用を示したのでその成績を 19-Nortestosterone phenylpropionate (19-NTPP) 及び Testosterone propionate (TP) と比較した. DS 系マウスを去勢後, 腫瘍を移植しその翌日から隔日

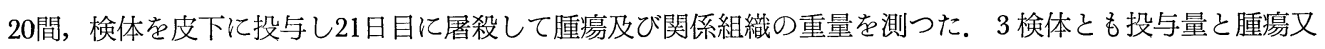
は関係組織との間に明らかな用量作用関係が認められ，TP を 1 としたときの相対力価は腫瘍では 10275-S が 6.1, 19-NTPP は5.7で, 挙肛筋, 腎及び精襄に於いては各々 19-NTPPより高い值を示した. 挙肛筋対 精襄の比は夫々 6.0 と 5.0 であつた. 即ち本検体は Anabolic activity の強いステロイドであるてとが䝷われ る. 次に ${ }^{3} \mathrm{H}$ が5，6位にラベルされた 10275-S，同じく1，2 位にラベルされた Testosterone による腫 瘍及び関係組織への uptake をみた。 前者は投与後 9 時間でピークに達し相当長く retain されたが, 後者 では投与後20分で既に最高に達し以後急激に減少した。 ホルモンに非依存性の Crocker sarcoma 180 での uptake は筋肉のそれと変りはなかつたが， Shionogi carcinoma 115 では両ステロイド共筋肉より明らか に高く，精襄と同様に男性ホルモンの標的組織としての性質を示した。

141. 卵巣門細胞腫の 1 例 
杉本 修, 井上 省蔵, 森崇 英, 余語 郁夫 卵巣門細胞腫は卵巣に発生するホルモン産生腫掦の中でも極めて稀な腫愓であり，てれまでの報告例は非 常に少ない，今回われわれは著明な男性化症状を伴なつた本腫瘍の 1 例を経験したので報告した。患者は 27 才の未婚婦人で続発性無月経と多毛を主訴として来院. 著明な男性化症状の他に内診によつて左側付属器部 に鷄卵大の腫瘤を触知した。臨床諸検査, 染色体分析の結果に異常を認めなかつたが内分泌学的検索により 尿中 17-K S が 83.7mg/day と異常高值を示した。 ての 17-K S は glucocorticoid によつて抑制されな いととおよび副腎系の機能検查成績が副腎性器症候群の反応パターンを示さなかつたてと等から, 腫瘍によ る男性化症状であると考元られた，後復膜気復腎撮影によつて副腎の腫煌を確認出来なかつたので男性化卵 巣腫湟の疑いで開腹し, 左側に発生した腫瘍を剔出組織学的検索を行なつた所, 閒細胞腫であつた。検索範 囲内では Reinke の crystaloid は証明出来なかつたが sudanophilia 陽性で $3 \beta$-ol dehydrogenase 活性も 組織化学的に証明可能であつたから，ての腫愓がステロイド生合成機能を持つているてとが確認された。な $お$ Testosterone production rate $1970 \mathrm{mg} /$ day, DHA secretion rate $90.9 \mathrm{mg} /$ day, DHA-sulfate secretion rate $9.2 \mathrm{mg} /$ day であり DHA, DHA-sulfate としてのみならず Testosterone の型で腫瘍から分泌されてい るものと考光られる。術後本症例は男性化症状の改善と正常月経周期の回復がもたらされた。

142. 膵疾患における上皮小体機能について

京大外科第一講座 水本 龍二, 吉良 勝正

愺臟と副甲状腺との間には相互関係があつて，一方の病的状態は他方の機能障害を薏起する可能性があり 最近注目を集めている，即ち，原発性副甲状腺機能方進症ではしばしば急性膵炎を合併し又粠の如きアルカ り性外分泌液を排出する導管内ではしばしば石灰沈着あるいは結石をおてして臟管閂塞ひいては慢性膵障害 を菍起してくると言われている，急性膵炎においては脂肪裻死部に Ca が沈着して低 $\mathrm{Ca}$ 血症をまねき二 次的副甲状腺機能 亢進を発生する可能性が存在する。慢性膵炎においては脂肪吸収障害 があつて脂溶性 Vitamin D ひいては Ca の吸収されない脂肪との Ca の結合は一周の吸収不良をおてす，てれにより血中 Ca 值の低下ををまねき二次的副甲状腺機能六進状態か溌生してよいだろう。我々は臨床上手術的にあるい は術中生検にて確認された膵疾患々者を主体として, 副甲状腺検査と膵機能検査とを同一症例に施行し膵と 副甲状腺機絈との相関性につき検索を行なつた，副甲状腺機能検査としては％TRP を膵機能検査として は Pancreozymin-Secretin Test 中の Vol $/ \mathrm{kg}$ 液量, $\mathrm{HCO}_{3}$ 濃度, Triolein Test, G.T.T. をとつて夫々の 相関につき検討してみた。 \% TRP と Vol $/ \mathrm{kg}$ 液量との相関は $\gamma=0.76$ で可成り高度の相関を示し又 $\mathrm{HCO}_{3}$ 濃度との相関比は $\gamma=0.63$ であつた。 \% TRP と尿中 Triolein 排泄率との相関比は $\gamma=0.7 \mathrm{~g}$ で最も高か つた，以上の如く我々の症例での成績は膵障害と Parathyroid Hyperfunction の相関は可成り高度である と言う結論を得た。

143. 甲状腺機能六進症に於ける副甲状腺機能について

名大日比野内科 中村 有三, 山内 昇, 富田 明夫

甲状腺機能立進症に於ける骨代謝異常については多くの報告があり, 我々の $\mathrm{Ca}^{45}$ Kinetic study によつ ても認められている。功る骨代謝異常状態に於ける副甲状腺機能については報告が少ない. 今回我々は未 治療の甲状腺機能元進症の患者について副甲状腺機能の検索を行なつた. 未治療の甲状腺機能九進症36例を 対象として血清 Ca, 血清無機燐濃度の測定. \% TRP, Ellsworth-Howard test を行ない, 夫々正常, 副甲状腺機能六進症，副甲状腺機能低下症と比較検討した．全例共，Ca $500 \mathrm{mg}, \mathrm{P} 1000 \mathrm{mg}$ の一定食慨と し％ TRP は午前中 2 回測定して平均值をとつた. Ellsworth-Howard Test は原法に従い. Parathormone $200 \mathrm{U}$ 投与後の尿燐排泄の増加率を求めた. 甲状腺機能六進症症例の血清 $\mathrm{Ca}$ は平均 $9.5 \mathrm{mg} / \mathrm{dl}$ で, 正 常例平均 $9.6 \mathrm{mg} / \mathrm{de}$ と有意差は認められなかつた。血清無機燐は平均 $3.8 \mathrm{mg} / \mathrm{dl}$ で正常平均 $3.6 \mathrm{mg} / \mathrm{dl}$ と の間に有意差は認められなかつた。 TRP の平均は $94.8 \%$ で正常例の平均 $86.0 \%$ と間に有意差が認めら れた. $(\mathrm{P}<0.01$ 自由度36) 甲状腺機能六進症に行なつた Ellsworth-Howord test では，12例中 3 例を除 きすべて $3 \sim 14$ 倍の尿燐排泄の増加をみた. 以上の結果から, 甲状腺機能立進症に於ける副甲状腺機能は低 
下の傾向にあると考えられる。

質 問 京大深瀬内科 井上 博 甲状腺機能立遊症例では, 血清 $\mathrm{Ca}$ 及び $\mathrm{P}$ が正常值であるにあ拘わ らず，\% TRP， Ellsworh-Howard 試験では副甲状腺機能低下症と同様の所見を呈し，両者の間に解離がみ られたが，乙の結果について御教示預きたい。甲状腺機能立進症では“Secondary hypoparathyroidism”を 有すると推定されるが.

応答: 名大日比野内科 中村 有三 我々の Kinetic study の結果から, Bone Resorption Rate は 六進しているので，ての六進した Bone Resorption を抑制しょうとする反応の表われとして副甲状腺機能 は低下の傾向にあると考えられる.

144. Parathormone 投与による血清 Al-P isozyme の変動について

京大泌尿器科 加藤 篤二, 酒德治三郎, 高橋 陽一, ○福山 拓夫 京大深瀬内科 井上 博

正常人に Parathormone を投与し，血清 Al-P isozyme の変動を観察し，骨疾患及び肝疾患における pattern と比較した. Al-P isozyme は disc electrophoresis 及び agar gel electrophoresis を用い， disodium $\alpha$-naphthyl phosphate, Fast Blue RR salt を用いて作製した. Parathormone の作用は尿中 P排泄 の変動を観察する事により確認した. disc でも agar gel でも zymogram に本質的な差異は認めず，従つ てより簡易に行ない得る agar gel 法の方が有利と考えられた. 健康成人の Al-P zymogram は agar gel では $\alpha_{2}$-globuline, disc では Trans ferrin の原点側から $\beta_{2}$ 及び Hapt. 1 にかけて主活性帯を原点付近に 微弱な活性帯をみるが，Parathormone 投与者では主活性带が原点側に向つて巾広くなる傾向を認めた。一 方骨疾患では agar gel 法において $\alpha_{2}$ より $\beta$ まで巾広く濃染した。 閉塞性肝疾患では $\alpha_{2}$ 部に濃染をみ, 実質性肝疾患では易動度が大になり $\alpha_{1}$ 側に偏位し，更に $\beta$ 位に弱い活性带の出現をみた。 agar gel 及び disc 法血清 Al-P Zymogram により肝疾患と骨疾患の鑑別は可能であつたが，Parathormone 投与者では 骨疾患肘の pattern に類似し，従つて骨疾患群からの区別は困難の様に思われた.

145. Simple Vitamin D Resistant Rickets の 1 例

京大小坚科 北条 博厚, 村石 喜邦, 長藤 洋 京大深瀬内科 并上 博, 河野 剛

8才 4 カ月女児の Vit. D Resistant Rickets の症例に於いて， Ca，P の balance study 副甲状腺機能検 査を中心に結果をのべた，家族歴には類似症なく， sporadic case と考朰れた．血清アルカリフォスファ ターゼ定値燐低值を示し，骨には典型的クル病性変化を認めた。糖尿，アミノ酸尿はなく，Tubular acidosis もみられなかつた，腸管よりの $\mathrm{Ca}, \mathrm{P}$ の吸収は正常に保たれていたが. 尿細管よりの燐の再吸収率は低 下し, hyperphosphaturic response がみられた. グルコン酸 $\mathrm{Ca}$ 静注, 副甲状腺ホルモン静注による検查 の結果は正常で secondary hyperparathyroidism の存在は認められなかつた.

146. Glycosuria と Aminoaciduria を伴なつた晚発性 Vitamin D Resistant

Rickets の 1 例

$\begin{array}{ll}\text { 天理よろづ相談所病院内分泌内科 } \text { 風間 善雄, 高山 英世 } \\ \text { 京大深瀬内科 } & \text { 井上 博, 河野 剛, 深瀬 政市 }\end{array}$

症例は17才の女性で，幼先期体格は小さい方であつたが，身体的発育には特に異常を認めなかつた，中爫 1 年頃より跛行をきたす様になり，15才頃より腰椎，股関節の変形を生じ歩行不能となつた．両親はいとと 結婚であり，同胞には 1 人の兄がいだ，本年 1 月蛋白尿を伴なつた不明の腎疾患にて死亡している. 入院 時体格は倭小, 胸骨部陥没, 股関節開排制限, 外反膝等を認める. 検尿で蛋白, 糖陽性, アミノ酸が著増し ている. PSP, クリアランスが稍低下しているが，腎盂撮影は正常である，尿酸性化障害無く，血清 $\mathrm{K}$ 正常， $\mathrm{Ca}$ は正常下界, Pは著減している, 骨X線では, 骨端線は開いているが, くる病特有の変化は無く, 皮質 の菲薄, 骨梁の粗大が著しい. 右肩甲骨, 肋骨には仮骨折を認める. 以上の結果糖尿とアミノ酸尿を有する 比較的晚発性のビタミンD抵抗性くる病, 就中 Fanconi 症候群に属するものと思われ, 更に次の検査を行 
なつた。即ち空腹時血糖は正常であるが，GTT では糖尿病型を示し，一方 TTT は全く正常であつた。 副甲状腺機能検査のうち，\% TRP は著减，PEI は高值を示したが，Ca 負荷試験，Ellsworth-Howard 試 験ではほぼ正常反応を呈した。本例の如き尿細管性くる病の場合の低 P 血症の成因については不明であるが, 上記検查結果より続発性副甲状腺機能立進症に由来するという見解よりむしろ近位尿細管に先天性異常があ つて，再吸収が抑制され，所謂 Phosphate leak を招来するという考光方を支持するものと思われる.

147. Pseudohypoparathyroidism の 1 例

国立福岡中央病院内科 $\bigcirc$ 矢野 雅之, 吉住 孝之 症例 61 才主婦. 両親に高血圧があり, 同胞 6 人中 4 人健在. 小学校の頃より背ひくく小学 4 年で紡績女工 として働く. 初経17才. 順，閉経期不詳. 24 才で結婚，40才で再婚し現在に至るも妊娠の既往なし. 昭和41 年10月頃より頭痛, 眩暉がひどくなり家事及び歩行にさしつかえる様になり, 初めて開業医を訪れ, 高血圧, 左心室肥大を指摘され，当院江紹介同年12月入院. 昭和 42 年 1 月，痙卛発作（全身性）あり．脳波検査で陰 性棘波を認め, Chevostek test 陽性，脳内石灭化像あり，円形顔貌，短指症，短嵒幹，なぞから仮性副甲状 腺機能低下症を疑い, Ellsworth-Howard test で, 副甲状腺ホルモン投与により尿中無機燐排泄増加のない ことから仮性副甲状腺機能低下症と診断した．本例は高令であるためか．血清カルシウム值及び無機燐の值 は正常範囲内であつたが尿への排泄量はかなり減少している。他の内分泌異常の合併はなく，甲状腺機能正 常, アルカリフオスファターゼ値正常, 血清蛋白正常範囲, 17KS, 170HCS 共にやや低下するも ACTH test は正常であつた. Chromosome も正常の $2 \mathrm{~A}+\mathrm{XX}$ であつた.

質問：別府野口病院 野口 志郎 1 1) 尿中 $\mathrm{P}$ の排泄量は低下か $2 ）$ Metacarpus は全ての指で短いが この点については. 3) Pseudohypoparathyroidism の diagnostic criteria は.

質問: 京大樑瀬内科 井上 博 Pseudohypoparathyroidism の criteria の一つとして, 血清 Caの 低下, 血清 $\mathbf{P}$ の上昇は極めて重要な生化学的所見と思う。従つて他の臨床所見とを総合的に考元, Pseudopseudohypoparathyroidism との移行型ではないと思われる。血清 $\mathrm{Mg}$ は測定されたか.

質問：名大日比野内科富田 明夫 1 .カルシュウム負荷試験はどのような反応を示したのだろうか. 2. 血清カルシュウムは正常範囲とのととだが，Psendohypoparathyroidism と pseudopseudohypoparathyroidism との鑑別が問題になるのではないだろうが，私も一応両者の移行型みたいなものを考えている.

応答：国立福岡中央病院矢野雅之 (1)尿中粼カルシュウムの排泄は低下している。低 Ca 血症によ ると思われる慢性テタ二一症状があり。短指症, 円形顔貌, 短躯幹, 脳内石灰化, 皮下石灰化などの身体症 状のいづれかがあり， ellsworth-howard test で尿中燐の排泄增加のない事を条件とする. (2)血中 Mgは定 量して抢らない. (3) Ca 負荷により変化はなかつた。 pseudopseudohypoparathyroidism との鑑別は, 痓栾, Chevosteck test 陽性などから pseudhypoparathyroidism であらうと考えた，

148. 仮性副甲状腺機能低下症の双生児例

長崎大高岡内科 宇佐 利隆, 石橋 英雄, 東 良三, 高橋 恵美, 和泉 元衛 石丸 忠彦

内耳性難聴家系の双生児に見られた仮性副甲状腺機能低下症と思われる一例を経験したので報告した。症 例，35才，家婦。家族歴では祖母，父，同胞の計 6 人に内耳性難聴を認める. 既往歴では，患者は双生児と して出産，12才頃より，進行性難聴を認めた。現病歴では，28才頃よりテタニー発作，眼瞼痤變，全身の硬

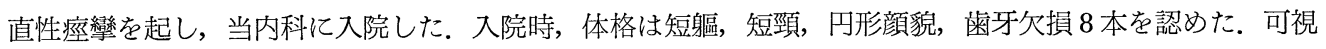
粘膜は貧血状で, 腹部に軽度の肝脾腫を認めた。神経学的に, Chvostek, Trousseau 微候陽性のほか異常を 認めなかつた。検査成績では，低色素性貧血あり，血清 P $5.1 \mathrm{mg} / \mathrm{dl}$ ，血清 $\mathrm{Ca} 5.6 \mathrm{mg} / \mathrm{dl}$ で，尿電解質は正 常であつた。IQは54で, 脳波では, 右後頭部にスパイク様速波を, 筋電図上, 未梢神経の異常興㚛性を認 めた。 レ線上, 骨及び皮下組織に異常所見なく, 染色体構成も正常であつた. 副甲状腺機能検査では, Sulkowitch 試験陰性，\% TRP は92\%で，Ga 負荷試験では尿中燐変化率は+70\%であつた。 EllsworthHoward 試験は対照6.9倍で, 本症例では2.8倍の増加をみた，その他の内分泌機能は正常であつた，症状は 
$\mathrm{Ca}$ 剤投与にて，軽快したが，血清 $\mathrm{Ca} ， \mathrm{P}$ は軽度の異常を持続した。尚，患者とは双生児の姉は滆歯のた め25才で総義歯を装着し，35才よりテタニー発作を認め，血清 $\mathrm{Ca} は 8.2 \mathrm{mg} / \mathrm{dl}$ であつた．ての事は従来云 われている遺伝的関係を示さしており，又，家族性内耳性難聴と本症とは共通の形成不全を合併し得る事は 興味深い.

質問：京大深瀬内科井上博 (1)異所性石灰沈着はあつたか。(2)短指症の部分はどてであるか.

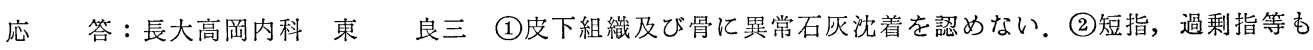
認めていない.

149. 視床下部性肥満における脂肪組織脂酸構成

徳島大油谷内科 桑田 勝夫, 近森 一正, 安岡 恒, 浜条 武久, 伊地 柴彦 三代 国雄, 坪崎 英治, 油谷 友三

視床下部肥満ラットの脂肪組織では, 視床下部損傷後早期より, 既に C18 $: 2 / \mathrm{C} 16: 0$ 比の低下が認めら れるととを前に報告した。我々は今回更に貯臓脂肪の部位による脂酸構成の差異及び体重変動の脂酸構成に 対する影響を検討した。いずれの部位の脂肪でも肥满は正常に比し, G16：0, G16:1の上昇及び C $18: 2$

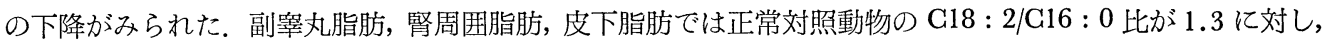
肥満動物では 0.7 とる．肩甲骨間脂肪では正常 1.0 に対し肥満 0.6 となる．視床下部性肥満動物ではその部 位を問わず, 脂肪組織脂酸構成は程度の差はあるものの, 一定の変化が認められた。. 次に摄食制限により肥 満ラットの体重減少を試みた，正常ラットより $60 \mathrm{~g}$ 少ない状態に達せしめ，ついでてれを自由摄食にもどし， 摂骨制限前の体重に近ずけた。乙の 3 時期の副蛙脂肪酸構成はほぼ不変で， $\mathrm{C} 18: 2 / \mathrm{C} 16: 0$ 比はいずれの 時期も 0.7 と低下している。乙れらの実験結果ならびに既報の視床下部損傷後体重増加がみられない早期よ り既に脂肪酸構成に変化がみられるとととあわせて，視床下部性肥満が単なる調節性肥満にとどまらず，そ の代謝機序にも何らかの変化が存するものと考える。

150. 副腎皮質ホルモンと髄質ホルモンの分泌と血中遊離脂酸について

名大環境医学研究所石原研究室 ○藤井 健策, 田村 好弘, 小森 義隆, 石原一郎

これまで，外因性に副腎皮質及び髄質ホルモンを投与した場合の血中遊離脂酸（FFA）の動員に関する報 告は多いが，乙れらのホルモンの内因性の分泌と血中 FFA との関連についての報告は少ない，そてで，我 々は，犬を用いて ACTH，アドレナリン及びインシュリンを投与した時の副骳 11-OHCS 及びカテコール アミン (CA) の分泌と血中 FFA を同時に測定し，此等の相互関係につき検討を加えた．未だ例数が少ない ので，確実な事は云い難いがおよそ次の様な結果が得られた。1）ACTH 投与時の如く，副腎 11-OHCS分 泌のみの増加では, 血中 FFA な変動しなかつた。 2) アドレナリン投与時の FFA 放出に際しては, 時を 同しくして，副腎 11-OHCS の分泌が高まつているので，アドレナリンの FFA の放出には，副腎皮質木 ルモンの関与が考えられる．３）インシュリンは，一方ではFFA の低下作用か認められたが，他方では副 腎 11-OHCS 及びGA 特にアドレナリンの分泌の增加により, 血中 FFA 上昇への作用をも引起すので, インシュリン投与時の FFA の変動は副腎 CA の分泌の早さ或は強さとに関連があると考えられる４４）イ ンシュリンの FFA 及び血糖低下作用は大量の Cortisol 投与によつても抑制されないが，その後の二次的 增加が表われない. 又副腎 CA の分泌の增加を伴なう場合にも FFA の二次的上昇が見られないので，大量 の外因性 Cortisol を投与した場合は，内因性 GAの FFA 放出作用を抑制するととも考学得られる.

質 問 京大深瀬内科 八幡三喜男 糖質コルチコイドの大量投与により, カテコールアミンの血中放出 は見られなかつたか。

応 答: 名大環研 藤井 健策 コーチゾール投与後の副腎カテコラミン分泌については検討していない.

151. glucocorticoids の脂質代謝に及ぼす影響についての研究（第 3 報）

異常脂肪沈着の成因について

阪大西川内科 足立 進, 礒崎 正弘, 石川 勝憲, 横村 徹, 西川 光夫 
Glucocorticoids 投与によつて起る異常脂肪沈着の成因を追求する目的で, モルモットに glucocorticoids を投与し, 脂肪組織よりの FFA release 及び脂肪組織での ${ }^{14} \mathrm{C}$-acetate (U), ${ }^{14} \mathrm{C}$-glucose (U) よりの脂質 合成に及ぼす影響を, white fat である epididymal fat と, brown fat である inter-scapular fat 亿つい て比較検討した. prednisolone 5mg を 2 週間筋注し FFA release をみると. interscapular fat では epididymal fat と異なり FFA release が低下するが，てれには脂肪組織自体の FFA release 能の低下と， 血清中の脂質動員に関与する諸因子に対する反応性の変化とが関係すると考えられる. 次に prednisolone 長期投与時の脂質合成に及ぼす影響をみると， ${ }^{14} \mathrm{C}$-acetate の総脂酸への取り込みは epididymal fat, interscapular fat で共に対照に比して減少している。 ${ }^{14} \mathrm{C}$-glucose の総脂質への取り込み及び $\mathrm{CO}_{2}$ への転化を みると, interscapular fat では総脂質への取り込みは epididymal fat と同様に増加しているが, $\mathrm{CO}_{2}$ へ の転化は epididymal fat と異なり逆に減少している. 次に interscapular fat の脂酸構成をみると, パル ミチン酸が増加し，リノール酸が減少しているが，てれは臨床的にみられる異常脂肪沈着者の皮下脂肪の脂 酸構成の変化に似ている。 モルモットの interscapular fat では, epididymal fat に比して FFA release が低下し, 又 ${ }^{14} \mathrm{C}$-glucose の総脂質への取り込みが増加するのに $\mathrm{CO}_{2}$ への転化が減少しているために脂肪 が増加すると考光られるが，臨床的に見られる buffalo hump type の異常脂肪沈着もこれと同様の機作に より起ると推測される.

152. 甲状腺機能充進症における糖代謝異常と血中遊離脂肪酸の動態について

京大深瀬内科 森本 昌親, 池田 正毅, 八幡三喜男, 井村 裕夫, 深瀬 政市 われわれは第39回本学会総会において, 甲状腺機能充進症では, 空腹時血中遊離脂酸 (FFA) の増加々耐 糖能の異常が高率に認められるととを報告した. その後更に症例を加光, 総計43例の本症患者において, 50gr. ブドー糖経口負荷試験 (GTT) の際の血糖, 血中 FFA, 血漿インスリン (IRI) の変動を観察し本症 における糖代謝異常の発現機序について考察を加えた。血糖曲線は43例中 33 例で異常がみられた. 空腹時血 中 FFA は平均 $642.6 \mu \mathrm{Eq} / 1$ (正常人の1.7倍) で，ブドー糖負荷に対する FFA の反応は GTT 正常のもの では急唆で, 耐桾能が低下するほど減少がゆるやかとなり前值への回復も遅延した。 IRI はGTT 正常の ものではほぼ正常であつたが. GTT が Oxyhyperglycemia のものでは過剩反応. 糖尿病型のものでは遅 延反応を示す例が多かつた。 また FFA と糖代謝異常の関係をみると，FFA が高値になるほど耐糖能が低 下寸る傾向がみられた． 空腹時血中 FFA と甲状腺機能とくに Triosorb との間に正の相関がみられた。抗 甲状腺療法によつて甲状腺機能か改善されると，FFA は低下し，血糖，FFAのブド一糖に対する反応も改 善された。甲状腺末を投与すると血中 FFA が上昇し，血糖曲線が悪化した．以上，甲状腺機能充進症にお いては甲状腺ホルモンの作用によつて Lipolysis が立進し, てれによつて増加した FFA が糖代謝異常の 発生に大きい役割を演じているものと考朰れる。

質問：阪大西川内科礒崎 正弘 Hyperthyroidism で体重が減少するあのが多いが，中には体重が 增加を示すすのあある。 それらの間で FFA の值に差はなかつたか.

応答：京大深瀬内科：森本 昌親 われわれは体重增加を来す例を経験していない.

153. 幼若ラット卵巣脂質への Palmitic Acid- $1-{ }^{14} \mathrm{C}$, Linoleic Acid- $1-{ }^{14} \mathrm{C}$ incorporation 及ぼすゴナドトロピンの影響

阪大第 2 病理 岡野 錦弥, 永井 清和, 花井 淳, 田中 要 我々は家鬼卵巣に於いて脂肪酸の卵巣内一の移動を in vitro で確めたが, gonadtropin がてれて対して 如何なる影響を及ばすかを知る目的で linoleic-acid-1- ${ }^{14} \mathrm{C}$, palmitic acid-1- ${ }^{-14} \mathrm{C}$ を用いて以下の実験を行な つた. 動物は体重 50gr 前後（生後 3〜 4 週）の幼若 Wistar 系雌性ラットを用いた. 実験群は 1) Control すなわち無処置群 2) FSH 25単位投与後 2 時間群 $3 ＼mathrm{~ ） ~ F S H ~} 3$ 投与後50時間群 4) FSH 投与後 50 時間で HCG（20単位）を更に追加72時間後の 4 群とした。卵巣 $120 \mathrm{mg}$ を採取し slice を作成，それを KrebsRinger phosphate 飞 $50 \mu \mathrm{g}$ の carrier を加えた $1 \mu \mathrm{C}$ の標識脂酸の $5 \% \mathrm{Et} \mathrm{OH}$ 懸濁液を medium として incubate した. Incubation time は 15',30', $1^{\circ}, 2^{\circ}$ とした. Incubation 終了後, medium を捨て更に組 
織表面に付着せる $\mathrm{C}^{14}$ 脂酸をよく洗つた slice のみにて脂質抽出を行なつた. 次に TLG を用いて Cholesterol-ester. Iriglyceride, NEFA, Phospholipid の四分画に分け，その各々の放射能活性を測定した. linoleic acid-1-G ${ }^{14}$ を medium に入れた場合 Gonadtropin 投与群では Triglyceride Cholesterol-ester 燐脂質の 何れの分画にも著明なとりこみの増加を認めたが palmitic acid-1-C'14 では軽度の増加を示したにすぎなか つた。 また Triglyceride Cholesterol-ester のとりとみ速度は Incubation time にほぼ比例するが Phospholipid では短時間でもとりてみの peak を示す.てのととは Triglyceride, Cholesterol-ester と Phospholipid の間に代謝様式の差があることを想定させ phospholipid の機能脂質としての特徽を現している.

154. Alloxan 糖尿ラット, Gold thioglucose 肥満マウス並びそ Alloxan 及び Gold thioglucose で処置した肥満糖尿マウスの血液, 肝臓及び脂肪組織の脂質及びその 脂酸構成

京大深瀬内科 岡部 純一, 説田 武

Eastman Kodak の Alloxan の 5 \%水溶液 $180 \mathrm{mg} / \mathrm{kg}$ を Wistar 系ラットの腹腔内に注射してAlloxan 糖尿ラットを作り, 又 Gold thioglucose $1 \mathrm{mg} / \mathrm{g}$ をD.D. 系マウスの腹腔内に注射して肥満過程のマウス 及び Alloxan と Gold thioglucose を同時に注射して肥満過程の Alloxan 糖尿マウスを作つて夫々血清 の中性脂肪 (T.G.), 遊離脂肪酸 (F.F.A.), 肝の T.G. 血漿，肝及び副殬丸周囲脂肪組織の各脂酸分画の脂酸構 成を各 3 例について測定した. 血清, 肝の T.G. は T.J. Anderson 等の方法, 血清 F.F.A. は Itaya \& U : の変法, 薄層クロマトで分離し得た各脂酸分画の脂酸構成をガスクロにて測定した. Alloxan 糖尿ラット の血清, 肝の T.G. は上昇し, 肝の総脂酸の脂酸構成ではパルミチン酸, パルミトオレイン酸の上昇, ステ アリン酸, アラキドン酸の低下がみられ，血漿，肝の T.G. 分画中オレハン酸の上昇，リノール酸，アラキ ドン酸の低下がみられた。乙れは Alloxan 糖尿ラットでは肝における T.G.の蓄積傾向を示唆するが，こ の点に関しては更に症例を重ねて検討する積りである. Gold thioglucose 肥満マウスでは肝の各脂酸分画 の脂酸構成でオレイン酸の上昇, リノール酸, アラキドン酸の低下がみられた。 との傾向は T.G. 燐脂質, コレステロール・エステル分画に著明であつた. Gold thioglucose と Alloxan の同時処買により作り得た 肥満糖尿マウスでは Alloxan 糖尿ラットの時と同様な傾向が血清, 肝の T.G. 及び血漿, 肝の T.G. 分画 の脂酸構成にみられた。

質問：德大油谷内科 油谷 友三お示しにあつた GT 投与マウスは肥満になつて居るか, 非肥満で あるか. GT 投与後何日位で代謝異常の検索をなさつたのか. 乙れらの GT 投与マウスの脳の変化を検索 なさつたか. 以上の 3 点を抢たづねする。

応答：京大深瀬内科 岡部 純一 1) Gold thioglucose 注射後35日目に処理したもので未だ完成され た肥満にはなつていなく，肥満の過程にあるものを材料として用いた．2）脳の方の組織は見ていない.

質問：德大油谷内科 安岡恒 アロキサン及びゴールドチオグルコースを同時に投与したマウスに おいては尿糖, 血糖は如何であるか, 又そのマウスの屠殺時期は投与後どの位であつたか.

応 答: 京大深瀬内科 岡部 純一 尿糖が出るが゙うかによつて糖尿マウスが出来ているかの Merk$\mathrm{mal}$ と一応し, 尿桾陽性のものの血桾を测定した。血糖值についてはスライドに扔示しした様に対照とは增 加している.

155. 糖尿病家系者の NEFA，ブドウ糖負荷時の NEFA 変動について

熊大体質医学研成人体質学研究部 三村 悟郎, 中村 專久, 福島 敬祐, 定永 竹志, 坂本 安弘 従来, 糖尿病における脂質代謝異常は糖代謝異常に伴なう二次的現象であると看做されて来たが, 最近脂 質代謝異常が糖尿病の発現に一次的役割をはたすと云う報告もみられる今回我々は糖尿病家系者に $50 \mathrm{~g}$ ブド ウ糖経口負荷試験を行ない，同時に NEFA，IRI を30分間隔で180分まで採血測定しその変動について検討 を行なつた，糖尿病家系25家系51名男17名女 34 名. 糖尿病患者を発端者とすると患者の親 2 名, 兄弟17名, 子供 28 名, 侽姪 4 名. 51 名中 GTT で糖尿病とされる者 9 名. 疑糖尿病 1 名. 正常が 41 名約 $80 \%$ でした, 糖尿病例の NEFA の変動は空腹時高く, 下り方もおくれ IRI はピークに達するまでの時間か涎長しその 
後の減少率も遅延する傾向を示した，GTT 正常家系者41名中 NEFA の変動異常を示すものが17名 (41.4 \%) IRI 異常 9 名であつた糖尿病家系者の中 GTT 正常の者の NEFA を糖尿病の家族歴のない若年者お よび40才以上の者の NEFA と比較すると最低値に達するまでの時間がやや遅れる傾向にあり，又家系者の 中の肥満者の NEFA は空腹時も高いが，最低值も高い傾向を示した．今後 PGTT 100g GTT を行なつ て比較検討してみる必要があると思われるが，糖尿病系者の内 50g GTT 正常者に NEFA 異常 IRI 異常 を示すものがいたてとは興味あるてとで糖尿病発症に対する NEFA の第一次的意義について現在のとてろ その本質は明らかでないが GTT 正常家系者に NEFA 異常者が存在することは興味ある閭題であると思 われる。

156. 重症筋無力症に対する胸腺剔出術の経験

京大木村外科 石上 浩一，鯉江 久昭，都志見久令男，増田 道彦 京大深瀬内科 井村 裕夫

京大小児科 森 忠三

京大整形外科 金 石珍

重症筋無力症に対する治療として胸腺剔出術を施行した報告は欧米においてはすでに数百例以上におよび その結論として本症の臨床経過は胸腺剔出によつて影々好結果がえられるてとが認められるに至つている。 京大第 2 外科にても最近 2 年間に手術例 3 例を経験した, 症例 1 は 6 年前から発病した 23 才女子で, 術後 2 年を経過しているが, Mytelase の所要量が術前の1/3以下にまで改善された。症例 2 は 8 ケ月前から発病し た 12 才女子で術後眼瞼下垂, 複視, 嚥下・発声障害等が全く消失し著効を認めた. 症例 3 は発病後 4 年の 38 才女子で術後 2 ケ月の現在病状の改善は余り認められてない.いづれの症例も胸腺腫は伴なわなかつた。剔 出胸腺の組織学所見は症例 1 及び症例 2 では髓質に泼中心をもつたリンパ滤胞の出現, 髄質の增生による皮 質の圧迫像が認められたが, 症例 3 では単に萎縮せる胸腺像にすぎなかつた. 又症例 2 では神経・筋接合部 の Ch.E を染色しててれを電顕で撮影したが，筋線維や筋肉の核の周囲にも Ch・E を認めてのような像は 正常人では殆んど認められないものであり, 本症例においてはての部に Ch.E の異常な分布のあることを 示しており興味ある知見かと思われる.

追加：質問：阪大第一外科 魚住 徹 吾々の教室であ先代武田義章教授の時代に Myasthenia Gravis の研究が行なわれ既に昭和38年の外科学会総会，会長演説でも述べている通りで，20例程の手術経験がある. その殆んど全例の胸腺に Germinal Gentre が存在し胸腺腫の認められたすのも数少くない. Myasthenia gravis の本態については，不明であるととは云われた通りであるが，教室の松山，中尾は，Myasthenia gravis 患者の血清中に choline の acetylationを inhibitする物質を発見し，現在更に追求中である.

応答: 京大木村外科 都志見久命男 症例 1 及び症例 2 では肧中心を認めたが症例 3 では単に菱縮した 胸腺のみで胚中心は認められなかつた。 又との症例 3 では胸腺剔出の効果は期待出来なかつた。

応答: 京大第二外科 石上 浩一 Desmedt は本症患者の笳内はへミコリニゥム 3 で処理された収縮 態度を示すという。本症における神経筋接合部の伝達障害にはアセチルコリンの合成障害, コリンエステラ 一ゼの比較的活性增大, 筋肉終末側の伝達物質飞対する閾值の変化等色々考元られ, 本症の中にも色々の夕 イプのあるととが予想される。 